\title{
Flood Hazard Recurence Frequencies for C-, F-, E-, S-, H-, Y-, and
} Z-Areas

by

K. F. Chen

Westinghouse Savannah River Company

Savannah River Site

Aiken, South Carolina 29808

This paper was prepared in connection with work done under the above contract number with the U.S.

Department of Energy. By acceptance of this paper, the publisher and/or recipient acknowledges the U.S. Government's right to retain a nonexclusive, royalty-free license in and to any copyright covering this paper, along with the right to reproduce and to authorize others to reproduce all or part of the copyrighted paper. 


\section{Flood Hazard Recurrence Frequencies for C-, F-, E-, S-, H-, Y- and Z-Areas (U)}

September 30, 1999

Westinghouse Savannah River Company Savannah River Site

Aiken, SC 29808 


\section{DISCLAIMER}

This report was prepared as an account of work sponsored by an agency of the United States Government. Neither the United States Government nor any agency thereof, nor any of their employees, makes any warranty, express or implied, or assumes any legal liability or responsibility for the accuracy, completeness, or usefulness of any information, apparatus, product, or process disclosed, or represents that its use would not infringe privately owned rights. Reference herein to any specific commercial product, process, or service by trade name, trademark, manufacturer, or otherwise does not necessarily constitute or imply its endorsement, recommendation, or favoring by the United States Government or any agency thereof. The views and opinions of authors expressed herein do not necessarily state or reflect those of the United States Government or any agency thereof.

This report has been reproduced directly from the best available copy.

Available to DOE and DOE contractors from the Office of Scientific and Technical Information, P.O. Box 62, Oak Ridge, TN 37831; prices available from (615) 576-8401.

Available to the public from the National Technical Information Service, U.S. Department of Commerce, 5285 Port Royal Road, Springfield, VA 22161. 


\section{DISCLAIMER}

Portions of this document may be illegible in electronic image products. Images are produced from the best available original document. 
WSRC-TR-99-00369

September 30, 1999

\section{Flood Hazard Recurrence Frequencies for C-, F-, E-, S-, $\mathrm{H}-, \mathrm{Y}$ - and Z-Areas (U)}
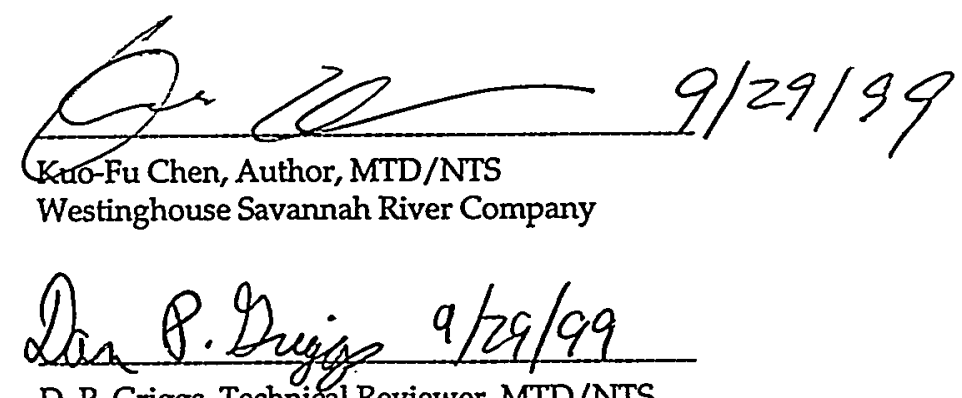

D. P. Griggs, Technical Reviewer, MTD/NTS

Westinghouse Savannah River Company

\section{Approved by:}

M. P. Addir (by aqu) 9/29/99

R. P. Addis, Manager, MTD/NTS

Westinghouse Savannah River Company

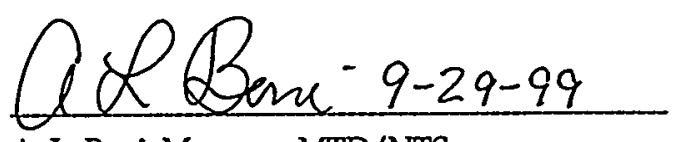

A. L. Boni, Manager, MTD/NTS

Westinghouse Savannah River Company

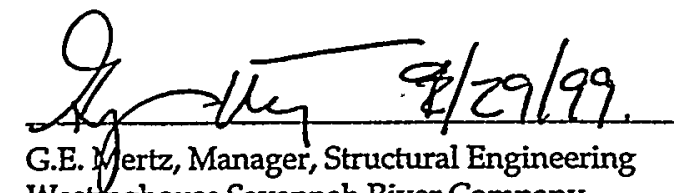

Westlmghouse Savannah River Company .

Prepared for the U.S. Department of Energy under Contract no. DE-AC09-96SR 18500 


\begin{abstract}
A method was developed to determine the probabilistic flood elevation curves for Savannah River Site (SRS) facilities. This report presents the method used to determine the probabilistic flood elevation curves for C-, F-, E-, H-, S-, Y- and Z-Areas due to runoff from the Upper Three Runs and Fourmile Branch basins. Department of Energy (DOE) Order 420.1, Facility Safety, outlines the requirements for Natural Phenomena Hazard (NPH) mitigation for new and existing DOE facilities. The NPH considered in this report is flooding. The facility-specific probabilistic flood hazard curve defines as a function of water elevation the annual probability of occurrence or the return period in years. Based on facility-specific probabilistic flood hazard curves and the nature of facility operations (e.g., involving hazardous or radioactive materials), facility managers can design permanent or temporary devices to prevent the propagation of flood on site, and develop emergency preparedness plans to mitigate the consequences of floods.
\end{abstract}




\section{TABLE OF CONTENTS}

1. BACKGROUND 1

2. METHODOLOGY 1

2.1. HEC-HMS Model 2

2.1.1. Measured Storm Event Hourly Rainfall 2

2.1.2. Determination of HEC-HMS Input Parameters 2

2.1.3. Measured Flows 3

3. CALCULATIONS 3

3.1. Design Hyetographs for SRS . 3

3.2. Upper Three Runs Basin

3.2.1. Upper Three Runs Basin Runoff Model 4

3.2.1.1. Rainfall Measurements for Upper Three Runs Basin 4

3.2.1.2. Upper Three Runs Flow Measurements 4

3.2.1.3. HEC-HMS Input Parameters for Upper Three Runs Basin 4

3.2.2. Upper Three Runs Basin Floods 5

3.2.3. Upper Three Runs Basin Flood Elevations 5

3.3. Fourmile Branch Basin 6

3.3.1. Fourmile Branch Basin Runoff Model 6

3.3.1.1. Rainfall Measurements for Fourmile Branch Basin 6

3.3.1.2. Fourmile Branch Basin Flow Measurements 7

3.3.1.3. HEC-HMS Input Parameters for Fourmile Branch Basin 7

3.3.2. Fourmile Branch Basin Floods

3.3.3. Fourmile Branch Basin Flood Elevations . 7

4. CONCLUSIONS 99

$\begin{array}{ll}\text { ACKNOWLEDGEMENTS } & 9\end{array}$

$\begin{array}{ll}\text { REFERENCES } & 10\end{array}$ 


\section{LIST OF TABLES}

Table 1 Six-Hour Storm Rainfall Distribution as a Function of Return Period

Table 2 HEC-HMS Parameters for Upper Three Runs Basin Runoff Model

Table 3 HEC-HMS Parameters for Fourmile Branch Basin Runoff Model

\section{LIST OF FIGURES}

Figure 1 SRS Map $\quad 13$

Figure 2 Rainfall in Inches from 12:00 am to 5:00 am EDT on August 22, 1990

Figure 3 Hourly Rainfall at Upper Three Runs Basin for 3/29/91 Storm Event 15

Figure 4 Hourly Rainfall at Upper Three Runs Basin for 1/6/95 Storm Event 16

Figure 5 Hourly Rainfall at Upper Three Runs Basin for 5/3/97 Storm Event 17

Figure 6 Measured Upper Three Runs Basin Runoff for 3/29/91 Storm Event 18

Figure 7 Measured Upper Three Runs Basin Runoff for 1/6/95 Storm Event 19

Figure 8 Measured Upper Three Runs Basin Runoff for 5/3/97 Storm Event 20

Figure 9 Calculated Upper Three Runs Basin Runoff for 3/29/91 Storm Event 21

Figure 10 Calculated Upper Three Runs Basin Runoff for 1/6/95 Storm Event 22

Figure 11 Calculated Upper Three Runs Basin Runoff for 5/3/97 Storm Event 23

Figure 12 Probability-Discharge for Upper Three Runs Basin at Station $02197310 \quad 24$

Figure 13 Flood Hazard Curves for Upper Three Runs Basin near F-Area 25

Figure 14 Flood Hazard Curves for Upper Three Runs Basin near S-Area 26

Figure 15 Flood Hazard Curves for Upper Three Runs Basin near Z- and Y-Areas $\quad 27$

Figure 16 Upper Three Runs Cross Section at Station S146C (near Z- and Y-Areas) 28

Figure 17 Hourly Rainfall at Fourmile Branch Basin for 1/6/95 Storm Event 29

Figure 18 Measured Hydrograph for Fourmile Branch at Stations 02197334 and 02197340 from 1/1/95 00:00 to 1/15/95 24:00 30

Figure 19 Measured Hydrograph for Fourmile Branch at Stations 02197342 and 02197344 from 1/1/95 00:00 to 1/15/95 24:00 31

Figure 20 Calculated Fourmile Branch Basin Runoff for 1/6/95 Storm at Station 0219733432

Figure 21 Calculated Fourmile Branch Basin Runoff for 1/6/95 Storm at Station 0219734033

Figure 22 Calculated Fourmile Branch Basin Runoff for 1/6/95 Storm at Station 0219734234

Figure 23 Calculated Fourmile Branch Basin Runoff for 1/6/95 Storm at Station 0219734435

Figure 24 Probability-Discharge for Fourmile Branch Basin 36

Figure 25 Rating Curve for Culverts at Road E-1 Crossing Fourmile Branch 37

Figure 26 Flood Hazard Curve for Fourmile Branch Basin near C-Area 38

Figure 27 Flood Hazard Curve for Fourmile Branch Basin near F-Area $\quad 39$

Figure 28 Flood Hazard Curve for Fourmile Branch Basin near E-Area 40

Figure 29 Flood Hazard Curve for Fourmile Branch Basin near H-Area 41 


\section{BACKGROUND}

Flooding can cause structural and non-structural damage, and interrupt critical functions, resulting in huge economic losses. More importantly, if the affected facility contains hazardous or radioactive materials, flooding may result in a significant environmental and health hazard. DOE Order 420.1, Facility Safety, outlines the requirements for Natural Phenomena Hazard (NPH) mitigation for new and existing DOE facilities. Specifically, NPH includes flood events. The facility-specific probabilistic flood hazard curve defines as a function of water elevation the annual probability of occurrence or the return period in years. It is required to determine the flood elevations as a function of return period up to 100,000 years for Savannah River Site (SRS) facilities. Based on facility-specific probabilistic flood hazard curves and the nature of facility operations (e.g., involving hazardous or radioactive materials), facility managers can design permanent or temporary devices to prevent the propagation of flooding on site, and develop emergency preparedness plans to mitigate the consequences of floods. The flood hazard curves for C-, F-, E-, H-, S-, Y- and Z-Areas due to runoff from the Upper Three Runs and Fourmile Branch basins are presented in this report.

\section{METHODOLOGY}

A straightforward way to determine probabilistic flood hazard curves is to conduct statistical analyses based on measured stream flow records. However, there are two reasons that the SRS stream flow records could not be used for flood hazard analyses. One is that the historical flow records include the effects of significant quantities of cooling water discharged from five SRS production reactors that operated for many years. The other is that the record periods (several decades) are too short to calculate a 100,000-year return flood. To address this, a basin hydrologic routing method was employed. The procedures used for the method are presented next.

Step 1. Hyetographs (rainfall depth or intensity as a function of time) for various return periods were synthesized based on rainfall intensity-duration-frequency data.

Step 2. The Hydrologic Modeling System computer code (HEC-HMS) [1] was used to calculate basin peak flow based on the hyetograph for a given return period and basin properties. The method used to determine the HEC-HMS input parameters for a basin runoff simulation is presented in Section 2.1.

Step 3. The peak flow calculated by HEC-HMS (Step 2) was then used in the Computer Model for Water Surface Profile Computations (WSPRO) [2] to calculate the flood water elevations. WSPRO was developed by the United States Geological Survey (USGS) for the Federal Highway Administration. WSPRO uses a step-backwater analysis method to calculate water surface elevations for one-dimensional, gradually-varied, steady flow through bridges and overtopping embankment.

Step 4. Steps 2 and 3 were repeated for each return period. 
Steps 1 through 5 were applied to both the Upper Three Runs and Formile Branch basins. The next section describes the procedures to obtain the HEC-HMS input parameters that are used in Step 2 to calculate basin peak flows.

\subsection{HEC-HMS Model}

HEC-HMS is a hydrologic modeling system developed by the US Army Corps of Engineers, Hydrologic Engineering Center, to model flood hydrology. HEC-HMS performs precipitationrunoff simulations. The HEC-HMS input data are precipitation and model parameters (i.e., losses, runoff transformation and base flow) characterizing the basin properties. The output of HEC-HMS is basin runoff discharge. The input parameters for the basins were determined by matching the HEC-HMS output ruoff discharge with the measured runoff discharge for the selected historical storm events. In this report, "basin runoff discharge" means the total volumetric flow rate in the creek, stream, or river.

\subsubsection{Measured Storm Event Hourly Rainfall}

The data on rainfall within SRS were recorded via a rain gauge network. There are 13 rain gauge stations distributed inside the SRS, as shown in Figure 1. Measurements are taken once a day (usually at $6 \mathrm{AM}$ ), except for the rain gauge at the Central Climatology Facility. The rain gauge reading at Central Climatology Facility is taken once every fifteen minutes.

The basin-average hourly precipitation is required to calculate basin runoff. The procedure used to convert the daily measured precipitation to basin-average hourly rainfall is presented next.

Step A. The average of the measured rainfall for a given storm event from the gauge stations that cover the basin was taken to be the average rainfall of that storm for the basin.

Step B. The 15-minutes rainfall measurements from the Central Climatology Facility were converted to hourly rainfall.

Step C. The rainfall distribution from Step B was normalized by total rainfall.

Step D. The basin-average hourly precipitation was obtained by multiplying the values from Step A and Step C.

\subsubsection{Determination of HEC-HMS Input Parameters}

The HEC-HMS input parameters are basin drainage area, loss rate, transform, and base flow. The basin drainage area was obtained from the USGS Water Resources Data book [3]. The area within a basin that is impervious to rain infiltration was estimated from the site map using the ArcView GIS system [4]. The parameters for loss were adjusted to match the measured peak flow. The parameters for the runoff transform model were adjusted to match the shape of the measured hydrograph, and the base flow model parameters were adjusted to match the measured base flow. The resulting parameters were then used by HEC-HMS to calculate basin peak flow using the design precipitation hyetographs (See Section 3.1). 


\subsubsection{Measured Flows}

The measured hourly flows used to determine the HEC-HMS input paramters were provided by the USGS, Columbia, SC District. The USGS maintains a network of monitoring stations at strategic locations on the Savannah River and SRS streams, and at SRS outfalls, to measure the flows, fluid temperatures, and stage highs.

The calculated results for Upper Three Runs Creek and Fourmile Branch basins are presented in this report. Figure 1 shows the SRS map pertinent to this study. This procedure will be applied to other onsite basins.

\section{CALCULATIONS}

Calculations for the flood elevations as a function of return years for Upper Three Runs and Fourmile Branch basins are presented in this section.

\subsection{Design Hyetographs for SRS}

The design precipitation hyetographs specific to SRS were developed based on historical data at or near SRS. The extreme point rainfall as a function of return period and the hourly-rainfall distribution for a given storm event was developed based upon historical precipitation data at or near SRS, as presented in References 5 and 6, respectively. A factor to convert the point precipitation depths to areal (region average) precipitation depths was estimated from a historical storm event at SRS, as shown in Figure 2 [7]. This storm was from 12:00 am to 5:00 am EDT on August 22, 1990. The factor that converts the point precipitation to region average precipitation was estimated by dividing the area weighted highest rainfall by total area weighted rainfall. Since the duration of this storm was 5 hours, the extreme point rainfall for a six hour storm was used to create the design hyetograph.

The hourly rainfall for a given return period storm at SRS is calculated by Equation 1 .

$$
I_{i j}=a F_{i} R_{j}
$$

where:

$I_{i j}=$ rainfall (inches) in hour " $i$ " ( $\left.i=1,6\right)$ and for $j$-year return period,

$R_{j}=$ total six-hour storm rainfall (inches) for $j$-year return period, obtained from Reference 5 ,

$F_{i}=$ fraction of rainfall in hour " $i$ " for a six-hour storm, obtained from Reference 6 , and

$a=0.53$, conversion factor from point rainfall to regional average rainfall, estimated from Reference 7.

Table 1 presents the design precipitation hyetograph at SRS for various return periods.

Section 3.2 presents the method to calculate the Upper Three Runs basin peak flow based on the design precipitation hyetographs derived in Section 3.1. 


\subsection{Upper Three Runs Basin}

Upper Three Runs is the longest and northernmost system in SRS and has a drainage area of over 195 square miles. The main channel flows in a southeasterly direction until it empties into the Savannah River. Three main tributaries are the Tinker Creek, McQueen Branch, and Tims Branch. SRS facilities influenced by the Upper Three Runs basin include B-, M-, A-, F-, H-, S-, and Z-Areas. Upper Three Runs is gauged near Highway 278 (station 02197300), at SRS road C (station 02197310), and at SRS Road A (station 02197315), as shown in Figure 1. There are six highway bridges and two railway bridges that cross Upper Three Runs. In addition, there are six powerline roads that cause contractions but do not cross Upper Three Runs. Upper Three Runs differs from the other five onsite streams in two respects: it is the only stream with headwaters arising outside the SRS, and it is the only stream that has never received heated discharges of cooling water from the production reactors.

\subsubsection{Upper Three Runs Basin Runoff Model}

Based on historical available storm and flow records, storm events on 3/29/91, 1/6/95 and 5/3/97 were used to determine the HEC-HMS input parameters that characterize the Upper Three Runs basin. The selected storms were isolated storm events and there was no rainfall for several days before and after the storm events. These storms are typical winter, spring and summer storm events that occur at SRS. The typical winter and spring season storms have longer shower durations, as shown in Figures 3 and 4. The typical summer storm at SRS is of short duration and high intensity, as shown in Figure 5.

\subsubsection{Rainfall Measurements for Upper Three Runs Basin}

The procedures described in Section 2.1.1 were used to estimate the hourly rainfall over the Upper Three Runs basin for the selected storm events. The average of the measured rainfall for a given storm event from the six rain gauges (773A, Barricade 2, 700A, 200-F, 200-H, and Barricade 3) that cover the Upper Three Runs basin was taken to be the average rainfall of that storm for the basin. Figures 3 through 5 show the basin-averaged hourly rainfall in the Upper Three Runs basin for the three storm events.

\subsubsection{Upper Three Runs Flow Measurements}

The measured hourly flows at the stations 02197300,02197310 and 02197315 during and after the three storm events are shown in Figures 6 to 8, respectively. These data were provided by the USGS, Columbia, SC District.

\subsubsection{HEC-HMS Input Parameters for Upper Three Runs Basin}

The procedures described in Section 2.1.2 were used to determine the HEC-HMS input parameters for the Upper Three Runs basin, as shown in Table 2. These input parameters for the Upper Three Runs basin were determined to match the measured flows at gauge station 02197310 for the selected storm events. The parameters for loss rate and base flow varied for 
different storm events, as shown in Table 2, because of the differences in ground soil and ground water conditions at the time of storm events.

The peak flows determined at gauge station 02197310 were applied to entire Upper Three Runs basin for flood elevation calculations. The reason for selecting the gauge station 02197310 for the entire Upper Three Runs basin is explained in Section 3.2.3. Figures 9 to 11 present the model hydrographs and the measured hydrographs at gauge station 02197310 for the storm events on $3 / 29 / 91,1 / 6 / 95$, and $5 / 3 / 97$, respectively.

\subsubsection{Upper Three Runs Basin Floods}

Three sets of peak flows at station 02197310 for various return-period storms were calculated by HEC-HMS using the design precipitation hyetographs derived from Section 3.1 and three sets of input parameters obtained from Section 3.2.1.3. The highest, the lowest, and the average of the three sets of the calculated peak flows are presented in Figure 12. The calculated 100year return flood at station 02197310 varies from 1660 to $2972 \mathrm{cfs}$. The 100 -year return flood calculated by the USGS using the measured peak flow records to fit the Log Pearson Type-III statistical model is $1620 \mathrm{cfs}$ [8]. This indicates that the 100-year return floods calculated by two independent methods are in good agreement, as shown in Figure 12.

Table 2 shows variation of infiltration that affects basin runoff discharges. For a given storm, low infiltration of the ground condition would cause a higher runoff flow and high infiltration would cause lower runoff flow. The HEC-HMS results for the Upper Three Runs basin show that, for a 50-year return storm event, the difference between the calculated high and low runoff discharges (resulting from variation of ground infiltration) is $87.6 \%$ of the low runoff flow. The difference reduces to $19.5 \%$ for a 100,000-year return storm event. The translation of flood flows into flood elevations is discussed in the next section.

\subsubsection{Upper Three Runs Basin Flood Elevations}

The flood elevations of the Upper Three Runs basin for various flows were calculated by the WSPRO computer code. The data required for WSPRO are flow, boundary condition, channel geometry and losses, and hydraulic characteristics of the bridges and road crossings.

There are six highway bridges and two railway bridges that cross Upper Three Runs. In addition, there are six powerline roads that cause contractions but do not cross Upper Three Runs. Personnel of the USGS, Columbia, SC district surveyed thirty-six cross-sections along Upper Three Runs creek and synthesized 110 additional cross-sections [8]. The synthesized cross-sections were developed using surveyed cross-section data and 7.5 minute series topographic maps. In addition, elevation data and structural geometry for all bridges were determined. Lanier [8] used these data to set up a WSPRO model to determine the 100-year recurrence-interval flood plain for Upper Three Runs. The cross-sections given by Lanier were extended in both banks to accommodate higher flood flows. The ArcView Geographic Information System was used to obtain the expanded cross-section data. 
In general, flow varies along the stream. Downstream flow is higher than upstream, if there are no downstream diversions. Therefore, the WSPRO input flow usually varies along the reach. However, Figures 6 to 8 show that the measured peak flows at the upstream gauge station 02197310 are higher than those at the downstream gauge station 02197315 (see Figure 1). It was decided to use the flows obtained from Section 3.2.2 in WSPRO to calculate the flood elevations for entire reach. This gives conservative results because those flows were derived at gauge station 02197310 . Figures 13 to 15 present the calculated flood elevations near F-, S-, and Y- and Z-Areas as a function of recurrence intervals. For a 100,000-year return flood, the calculated flood elevations at F-, S-, and Y- and Z- Areas are 146, 153 and 160 feet above mean sea level (msl), respectively. The elevations of F-, S-, and Y- and Z- Areas are above 260, 250 and 240 feet msl, respectively. Therefore, the chances of flooding for those facilities would be very small.

Figure 15 shows that for a high flow condition, at 1.0E-05 annual probability of exceedance, the rate change of elevation decreases. This is caused by a sudden expansion of the flood plain at the corresponding elevation as shown in Figure 16.

For a 50-year return storm event, the difference between the calculated high and low flood levels (resulting from variation of ground infiltration) is 1.47 feet near F-Area. The difference reduces to 1.29 feet for a 100,000-year return storm event. F-Area is about 114 feet above the calculated 100,000-year return flood level. Therefore, the effect of the infiltration variation on flood elevation is very small compared to the flood margin.

\subsection{Fourmile Branch Basin}

The Fourmile Branch basin has about 23 square miles of drainage area including much of $\mathrm{F}-, \mathrm{H}$, and C-Areas. The stream flows to the southwest into the Savannah River Swamp and then into the Savannah River. The banks vary from fairly steep to gently sloping. The floodplain is up to 1,000 feet wide. Foumile Branch receives effluents from F-, H-, and C-Areas, from a groundwater plume from the Burial Ground and $\mathrm{F}$ and $\mathrm{H}$ seepage basins, and until June 1985, received large volumes of cooling water from the production reactor in C Area. Figure 1 shows the gauge stations 02197334, 02197340, 02197342, and 02197344 on Fourmile Branch. There are four highway bridges, one railway bridge, five culvert crossings, and ten breached dams or road beds that cross Fourmile Branch.

\subsubsection{Fourmile Branch Basin Runoff Model}

As discussed in Section 3.2.3, the effect of variations in basin infiltration on the flood elevation is very small in comparison to the flood margin. Therefore, one storm event (1/6/95 storm) was used to develop the Fourmile Branch basin runoff characteristics. The 1/6/95 storm was chosen because it had highest rainfall intensity and the largest accumulated rainfall.

\subsubsection{Rainfall Measurements for Fourmile Branch Basin}

The procedures described in Section 2.1.1 were used to estimate the hourly rainfall over the Fourmile Branch basin for the 1/6/95 storm event. The average measured rainfall from the six 
rain gauges (200-H, 200-F, 100-C, CLM, 100-K and 400-D) that cover the Fourmile Branch basin was taken as the average rainfall for the Fourmile Branch basin. The Fourmile Branch basin hourly rainfall for the 1/6/95 storm event is shown in Figure 17. The hourly rainfall amount are somewhat lower than these obtained for the Upper Three Runs basin (Figure 4).

\subsubsection{Fourmile Branch Flow Measurements}

The measured hourly flows for Fourmile Branch at the stations 02197334, 02197340, 02197342 and 02197344, as shown in Figures 18 and 19, were provided by the USGS, Columbia, SC District. The drainage area associated with a gauge station includes drainage area of upstream stations. Therefore, each station has different drainage area, as shown in Figure 1.

\subsubsection{HEC-HMS Input Parameters for Fourmile Branch Basin}

As discussed in Section 3.2.3, flow varies along the stream and is a function of sub-basin properties. Unlike Upper Three Runs, the measured peak flows increase as gauges are located further downstream. Therefore, the Fourmile Branch basin was divided into four sub-basins at gauge stations $02197334,02197340,02197342$ and 02197344 . The sub-basin properties (HECHMS input parameters) were determined by matching the model hydrographs with the measured hydrographs at the four gauge stations. Table 3 presents the parameters obtained for the sub-basins. Figures 20 through 23 present the calculated and the measured hydrographs for Fourmile Branch basin during the 1/6/95 storm event at gauge stations 02197334, 02197340, 02197342, and 02197344, respectively.

\subsubsection{Fourmile Branch Basin Floods}

HEC-HMS used the data from Section 3.3.1.3 (Table 3) and the design precipitation hyetographs from Section 3.1 to calculate the peak flows at gauge stations 02197334 , 02197340,02197342 , and 02197344 as a function of return period. Figure 24 shows the calculated peak flows as a function of return period or annual probability of exceedance. The peak flows were used by WSPRO to calculate the flood elevations, as described next.

\subsubsection{Fourmile Branch Flood Elevations}

Lanier [9] conducted a 100-year recurrence-interval flood plain study for Fourmile Branch Basin in 1996. To conduct the study, 49 cross-sections along the Fourmile Branch were surveyed and 132 synthesized cross-sections were developed. The synthesized cross-sections were developed by using surveyed cross-section data and the 7.5 minute series topographic maps. In addition, elevation data and structural geometry for 4 highway bridges, 1 railway bridge, 5 culvert crossings, and 10 breached dams or old road-beds were determined. Lanier used these data to set up a WSPRO model to determine the 100-year recurrence-interval flood plain for Fourmile Branch. The cross-sections developed by Lanier were extended in both banks to accommodate higher flood flows. The ArcView Geographic Information System was used to obtain the expanded cross-section data. 
WSPRO models the basin by subdividing the basin in segments and calculates the water elevation from downstream segment to upstream segment. WSPRO allows different flow at different segments. For Upper Three Runs, the measured downstream (higher drainage area) peak flows were lower than the measured upstream (lower drainage area) flows. Therefore, it was decided that the flows obtained at gauge station 02197310 were applied to the downstream segments to given conservative results, as described in Section 3.2.3. For Fourmile Branch, the peak flow decreases as drainage area decreases. Therefore, the WSPRO input flow varies along the segment according to the drainage area. The peak discharge was linearly interpolated between drainage areas except for one situation. To avoid extrapolation, the peak discharge at station 02197334 (drainage area of 5.59 square miles) was used for the upstream locations where the drainage area is less than 5.59 square miles. This gives conservative (higher) flood elevations.

One complicating factor in modeling flooding in Fourmile Branch is the presence of five culvert crossings. The WSPRO model cannot calculate the backwater caused by culverts. Therefore, a separate culvert-flow computation must be made to determine the backwater caused by the culvert. The Culvert Analysis Program (CAP) [10] was used to calculate the backwater surface elevations caused by culverts. The CAP code was developed by the USGS and is in the public domain. The calculation procedures used by CAP are based on those presented in Techniques of Water-Resources Investigations of the United States Geological Survey, book 3, chapter A3, "Measurement of Peak Discharge at Culverts by Indirect Methods." [11]

The analysis of culverts is complicated because they provide a parallel path for flood floods. Under normal conditions, water flows only through the opening in the culvert. Under flooding conditions, the water elevation may exceed the height of the road crossing, resulting in flow over the road crossing as well as through the culvert. This parallel flow path affects the calculation of the flood elevation upstream of the culvert.

For a given return period flow, WSPRO calculated subcritical flow water elevations from downstream to the exit location of a culvert. The water elevation upstream of a culvert was determined from a culvert rating curve. The culvert rating curve is, for a given downstream water elevation, the culvert upstream water elevation as a function of total flow (sum of flow through culvert and overtopping road crossing). This water elevation was used as a boundary condition for the WSPRO analysis of the next upstream reach. The procedure to obtain the culvert rating curves is presented next.

Step I. The CAP code used the culvert downstream water elevation as a boundary condition to calculate the culvert upstream elevations as a function of flows through the culvert. In this calculation, an imaginary vertical wall was at the inlet of culvert preventing flow over the road surface.

Step II. For the same given downstream elevation, WSPRO was used to calculate the upstream elevation as a function of flow over the road crossing. 
Step III. For the same downstream elevation and a specified upstream elevation, the total flow is the sum of flow through the culvert (Step 1) and overtopping the road crossing (Step 2). The culvert rating-curve is a plot of upstream water elevation versus total flow.

Using this procedure, the rating curves for the five culverts were obtained sequentially, beginning with the most downstream culvert. The downstream elevation for the first culvert is available directly from a WASPro analysis. Once the rating curve is obtained, the water elevation upstream of the culvert is determined by the known total flow (flood flow). This water elevation is used as a boundary condition for the WSPRO analysis of the next upstream reach.

Figure 25 shows the rating curve for the culverts at Road E-1. The triangles (two kinds of culverts at Road E-1) in Figure 25 show the calculated culvert upstream water elevation as a function of flow through the culverts. The squares in Figure 25 represent the calculated culvert upstream water elevation as a function of flow over the road crossing. The summation of the flows through culverts and over road crossing is the culvert rating-curve, as indicated by circles in Figure 25. For a specified flow (500-year return flow in this case), the culvert upstream water elevation is determined from the rating curve. At each culvert location, eight rating curves were established, one for each return-period flow.

Figures 26 to 29 present the calculated Fourmile Branch basin flood hazard curves near C-, F-, $\mathrm{E}-$, and H-Areas, respectively. The calculated annual probability of 1.E-05 (100,000-year return) flood elevation at C-Area is 189.7 feet msl, F-Area is 194.1 feet msl, E-Area is 203.0 feet msl, and H-Area is 236.8 feet msl. The elevation of C-Area is above 280 feet msl, the FArea is above 260 feet msl, the E-Area is above $280 \mathrm{msl}$, and H-Area is above 270 feet $\mathrm{msl}$. Therefore, the chances of flooding the facilities at C-, F-, E-, and H-Areas would be significantly less than 1.E-05 per year.

\section{CONCLUSIONS}

A method based on precipitation, basin runoff and open channel hydraulics was developed to determine the probabilistic flood hazard curve for Upper.Three Runs and Fourmile Branch basins near C-, F-, E-, S-, H-, Y- and Z-Areas. The calculated results show that the chances of flooding at C-, F-, E-, S-, H-, Y- and Z-Areas are significantly less than 1.E-05 per year.

\section{ACKNOWLEDGMENTS}

The work performed for this project was funded by the U. S. Department of Energy under contract DE-AC09-96SR18500. The author wishes to express special thanks to personnel at USGS, Columbia, SC, district: T.H. Lanier for providing the WSPRO input files and having valuable discussions during the model development; T.W. Cooney, F. Melendez, and B.W. Church for providing the hourly flow records. 


\section{REFERENCES}

1. HEC-HMS Hydrologic Modeling System, User's Manual, Version 1.0, US Army Corps of Engineers, Hydrologic Engineering Center, Davis, California, (1998).

2. J.O. Shearman, User's Manual for WSPRO-A Computer Model for Water Surface Profile Computations, FHWA-IP-89--27, Research, Development, and Technology, Turner-Fairbank Highway Research Center, McLean, Virginia, (1990).

3. T.W. Cooney, K.H. Jones, P.A. Drewes, J.W. Gissendanner, and B.W. Church, Water Resources Data South Carolina Water Year 1995, USGS, Columbia, South Carolina, (1995).

4. ArcView Version 3.0a, Copyright (๑), Environmental Systems Research Institute, Inc.

5. A.H. Weber, J.H. Weber, M.J. Parker, C.H. Hunter, and C.O. Minyard, Tornado, Maximum Wind Gust, and Extreme Rainfall Event Recurrence Frequencies at the Savannah River Site (U), WSRC-TR-98-00329, p. 30, Westinghouse Savannah River Company, Aiken, South Carolina, (1998).

6. C.H. Hunter, Estimated Sequential Hourly Rainfall Intensities for 6-Hour and 24-Hour Storms, (Internal Memo), SRT-NTS-99-0007, Table 1, Westinghouse Savannah River Company, Aiken, South Carolina, January 6, 1999.

7. R.P. Addis and R.J. Kurzeja, Heavy Rainfall at the SRS in July, August, and October of 1990 (U), WSRC-TR-92-136, Figure 9, Westinghouse Savannah River Company, Aiken, South Carolina, (1992).

8. T.H. Lanier, Determination of the 100-Year Flood Plain on Upper Three Runs and Selected Tributaries, and the Savannah River at the Savannah River Site, South Carolina, 1995, p. 7, USGS Water-Resources Investigations Report 96-4014, (1996)

9. T.H. Lanier, Determination of the 100-Year Flood Plain on Fourmile Branch at the Savannah River Site, South Carolina, 1996, p. 8, USGS Water-Resources Investigations Report 96-4271, (1997)

10. J.M. Fulford, User's Guide to the Culvert Analysis Program, USGS Open-File 95-137, (1995)

11. G.L. Bodhaine, Measurement of Peak Discharge at Culverts by Indirect Methods, USGS, Techniques of Water Resources Investigation, Book 3, Chapter A3, 60p. (1968) 
Table 1. Six-Hour Storm Rainfall Distribution as a Function of Return Period

$\begin{array}{rccccccc}\begin{array}{c}\text { Return Period } \\ \text { years }\end{array} & \begin{array}{c}\text { Hour 1 } \\ \text { in }\end{array} & \begin{array}{c}\text { Hour 2 } \\ \text { in }\end{array} & \begin{array}{c}\text { Hour 3 } \\ \text { in }\end{array} & \begin{array}{c}\text { Hour 4 } \\ \text { in }\end{array} & \begin{array}{c}\text { Hour 5 } \\ \text { in }\end{array} & \begin{array}{c}\text { Hour 6 } \\ \text { in }\end{array} & \begin{array}{c}\text { Accumulation } \\ \text { in }\end{array} \\ 50 & 0.13 & 0.33 & 1.22 & 0.71 & 0.20 & 0.07 & 2.65 \\ 100 & 0.15 & 0.37 & 1.39 & 0.81 & 0.22 & 0.08 & 3.02 \\ 500 & 0.19 & 0.48 & 1.80 & 1.05 & 0.29 & 0.11 & 3.92 \\ 1,000 & 0.22 & 0.54 & 2.02 & 1.17 & 0.33 & 0.12 & 4.40 \\ 5,000 & 0.28 & 0.70 & 2.61 & 1.51 & 0.42 & 0.15 & 5.67 \\ 10,000 & 0.31 & 0.77 & 2.88 & 1.67 & 0.46 & 0.17 & 6.25 \\ 50,000 & 0.39 & 0.98 & 3.68 & 2.14 & 0.59 & 0.22 & 8.00 \\ 100,000 & 0.43 & 1.09 & 4.07 & 2.36 & 0.65 & 0.24 & 8.85\end{array}$


Table 2. HEC-HMS Parameters for Upper Three Runs Basin Runoff Model

\author{
Basin Area $\left(\mathrm{mi}^{2}\right)$ \\ Loss Rate: \\ method \\ initial loss (in) \\ constant rate $(\mathrm{in} / \mathrm{hr})$ \\ imperviousness (\%) \\ Transform: \\ method \\ SCS lag (minute) \\ Base flow: \\ method \\ initial flow $\left(\mathrm{ft}^{3} / \mathrm{s}\right)$ \\ recession constant \\ thresholds flow $\left(\mathrm{ft}^{3} / \mathrm{s}\right)$
}

$\begin{array}{ccc}\frac{3 / 29 / 91 \text { Storm }}{176} & \frac{1 / 6 / 95 \text { Storm }}{176} & \frac{5 / 3 / 97 \text { Storm }}{176} \\ \text { initial/constant } & \text { initial/constant } & \text { initial/constant } \\ 0.0 & 0.0 & 0.0 \\ 0.555 & 0.870 & 0.715 \\ 2 & 2 & 2 \\ . & & \\ \text { SCS } & \text { SCS } & \text { SCS } \\ 2000 & 2000 & 2000 \\ & & - \\ \text { recession } & \text { recession } & \text { recession } \\ 160 & 250 & 190 \\ 0.965 & 0.965 & 0.965 \\ 200 & 320 & 200\end{array}$

Table 3. HEC-HMS Parameters for Fourmile Branch Basin Runoff Model

Basin Area $\left(\mathrm{mi}^{2}\right)$

Loss Rate:

method

initial loss (in)

constant rate (in/ $/ \mathrm{hr})$

imperviousness (\%)

Transform:

method

SCS lag (minute)

Base flow:

method

initial flow $\left(\mathrm{ft}^{3} / \mathrm{s}\right)$

recession constant

thresholds flow $\left(\mathrm{ft}^{3} / \mathrm{s}\right)$ $\underline{02197334}$

5.95

initial/constant initial/constant

0.0

0.8

5

SCS

400

recession

9

1

18 $\frac{02197340}{7.53}$

0.0

0.78

6

SCS

400

recession
11
1
18

$\frac{02197342}{12.5}$

$\underline{02197344}$

22
0.0
0.715
SCS
cession
0.965 
Figure 1 Savannah River Site Map

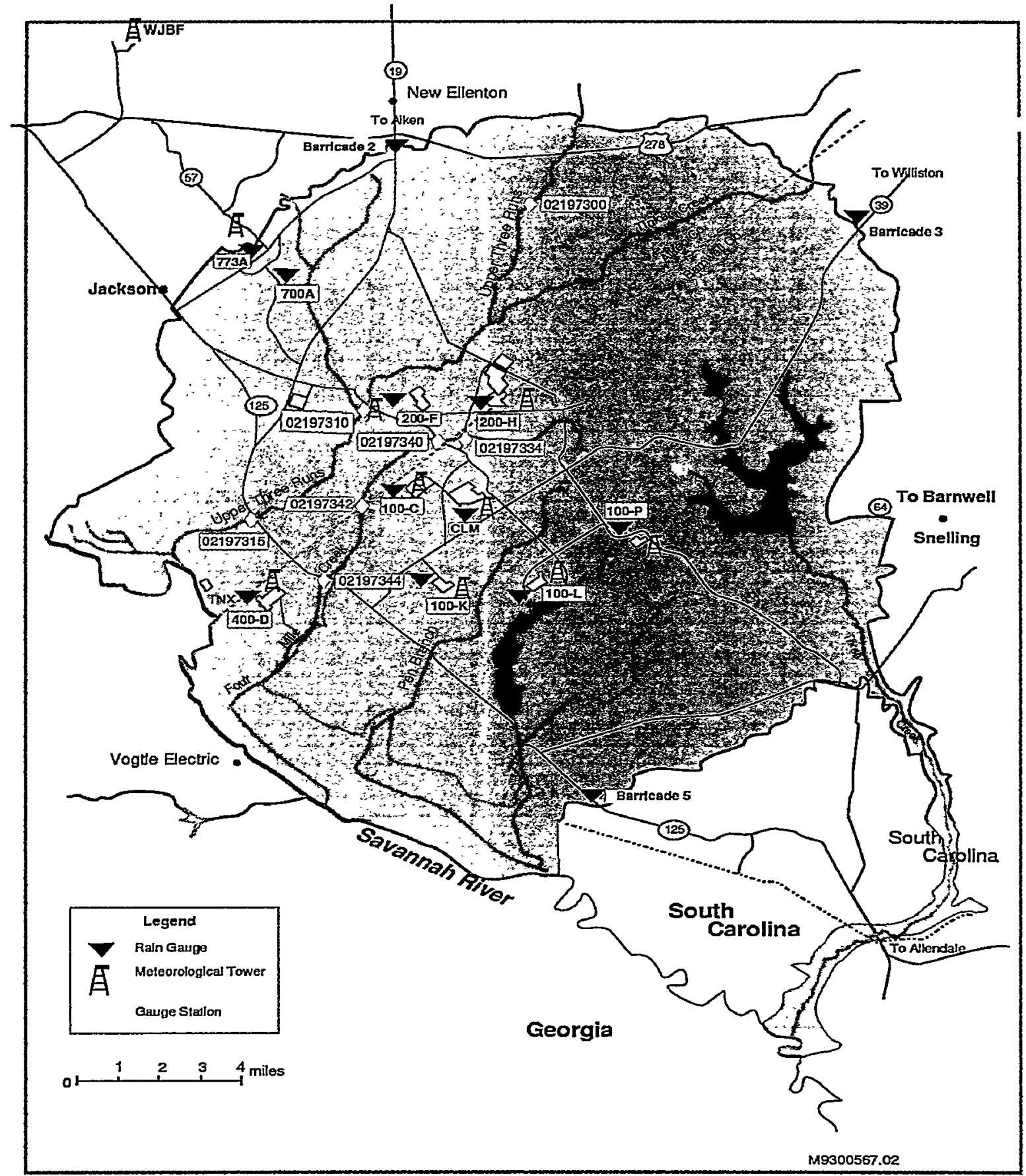


WESTINGHOUSE SAVANNAH RIVER COMPANY

WSRC-TR-99-00369

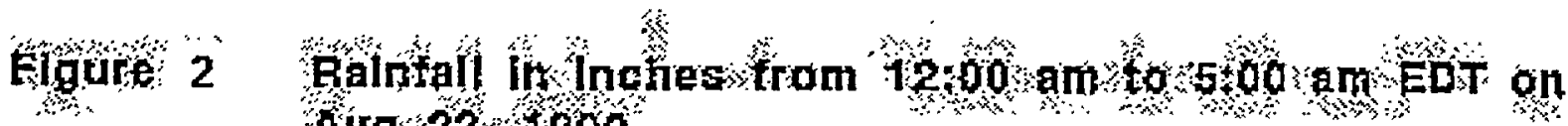
iug 22,1590 .

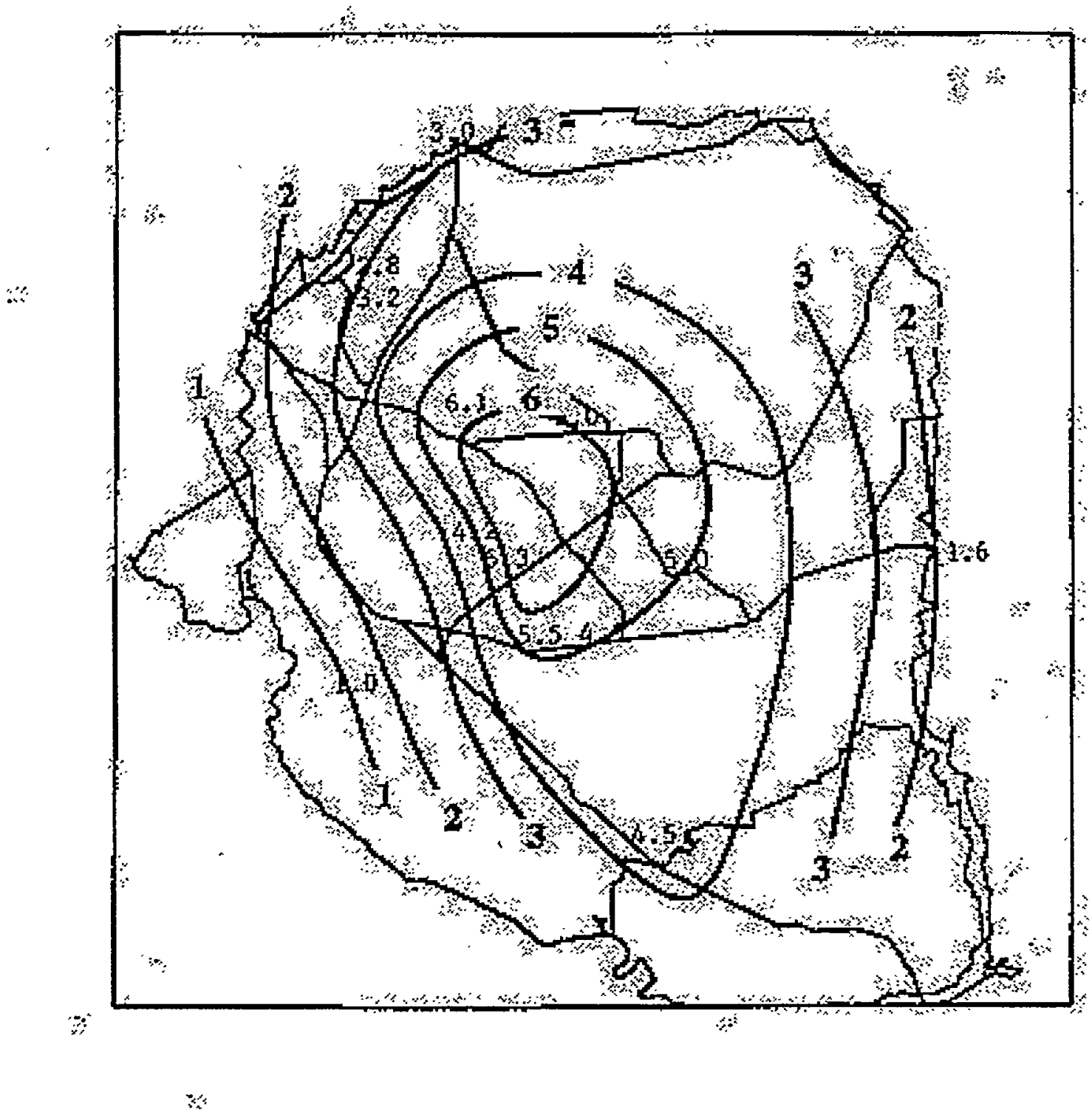




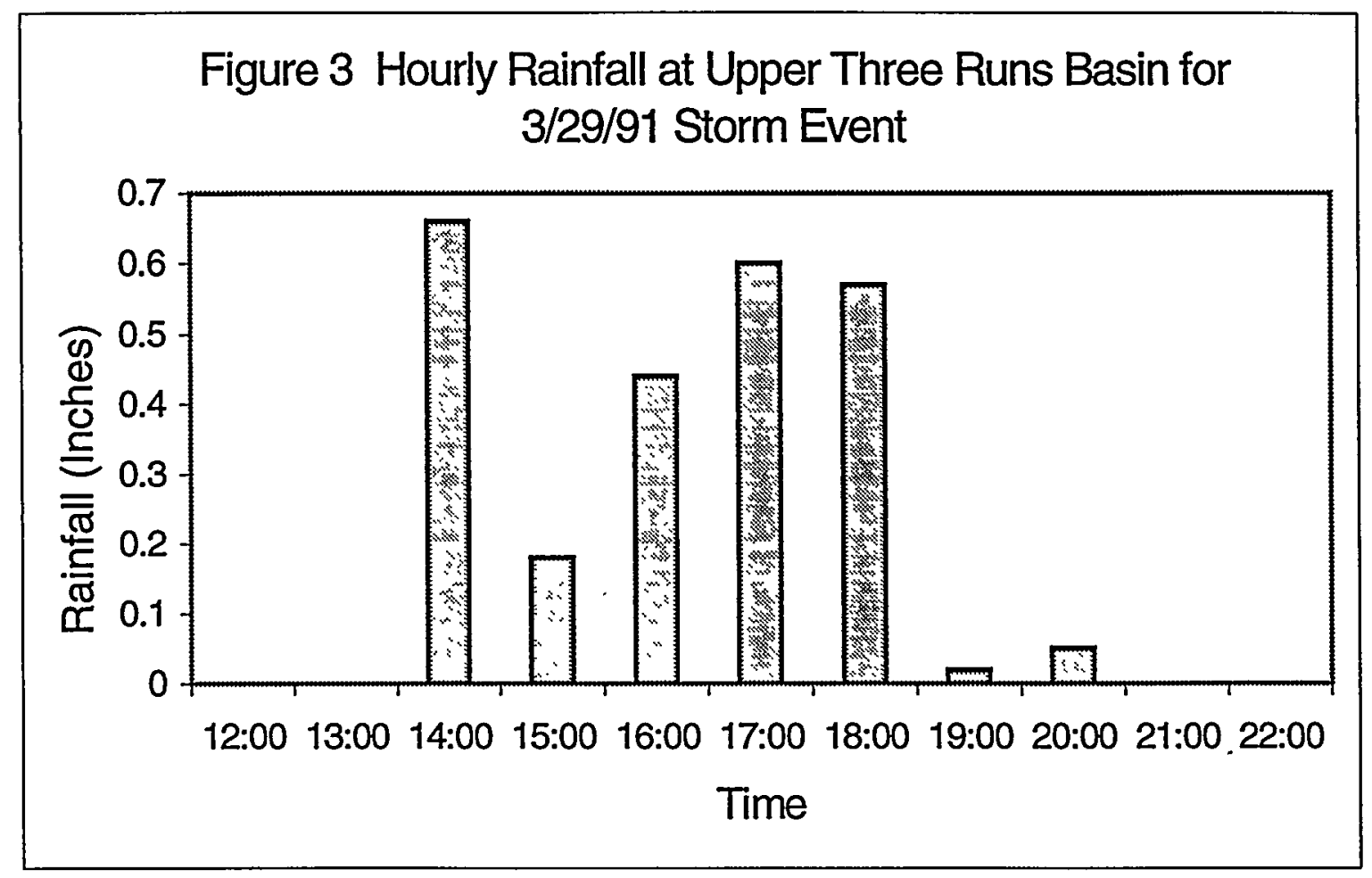


Figure 4 Hourly Rainfall at Upper Three Runs Basin for 1/6/95 Storm Event

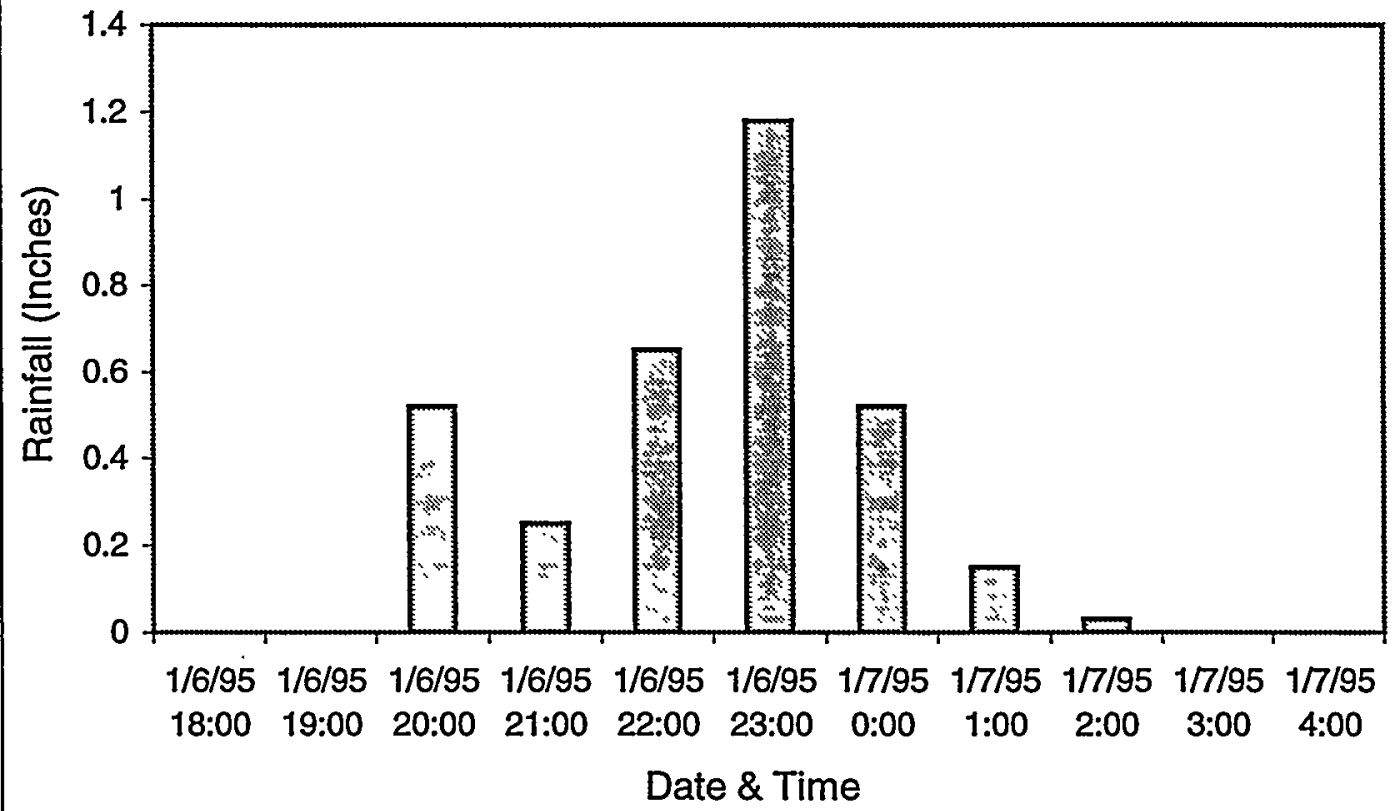




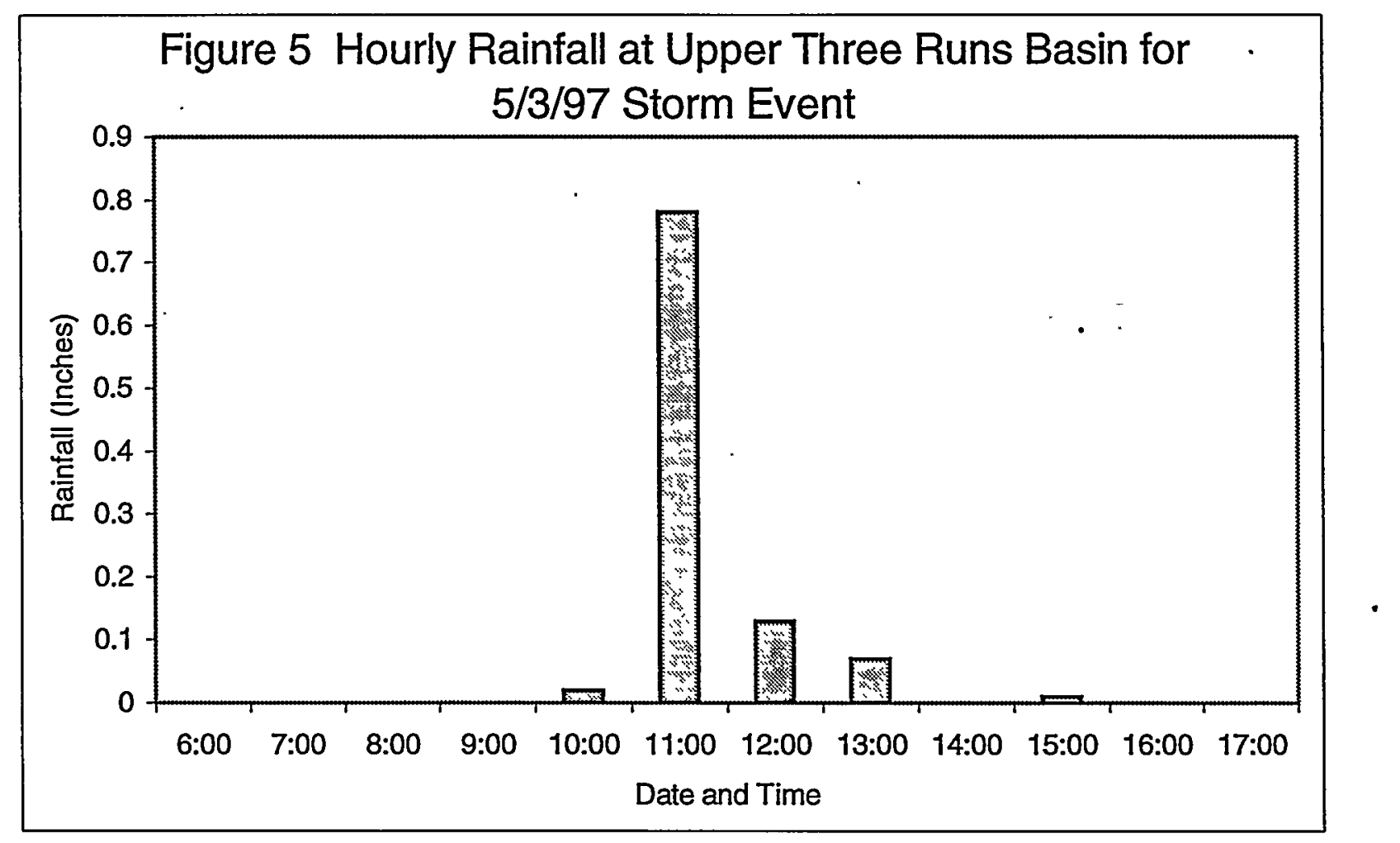


Figure 6 Measured Upper Three Runs Basin Runoff for 3/29/91 Storm Event (Time Zero at 3/29/91 00:00)

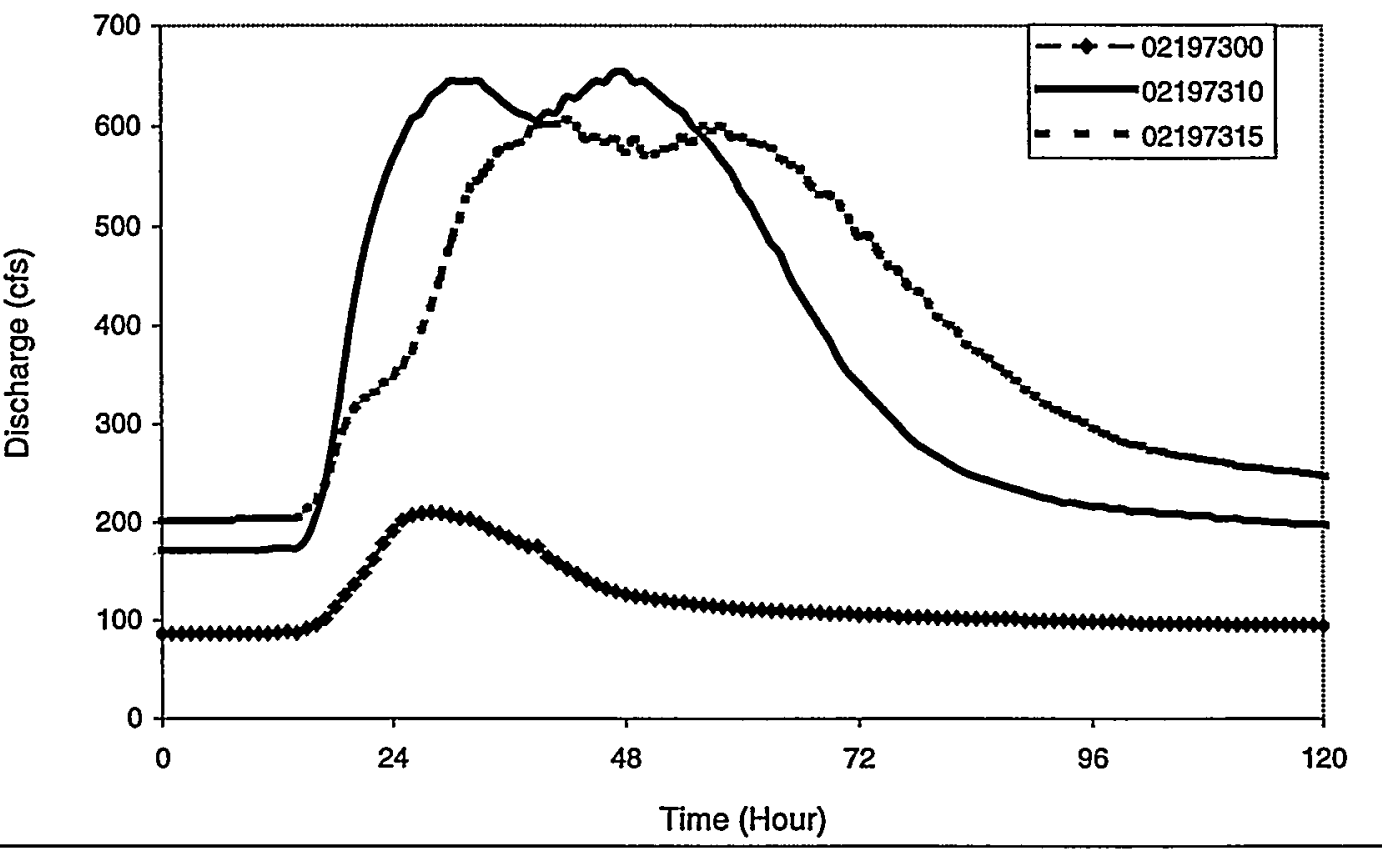


Figure 7 Measured Upper Three Runs Basin Runoff for 1/6/95 Storm Event (Time Zero at 1/6/95 12:00)

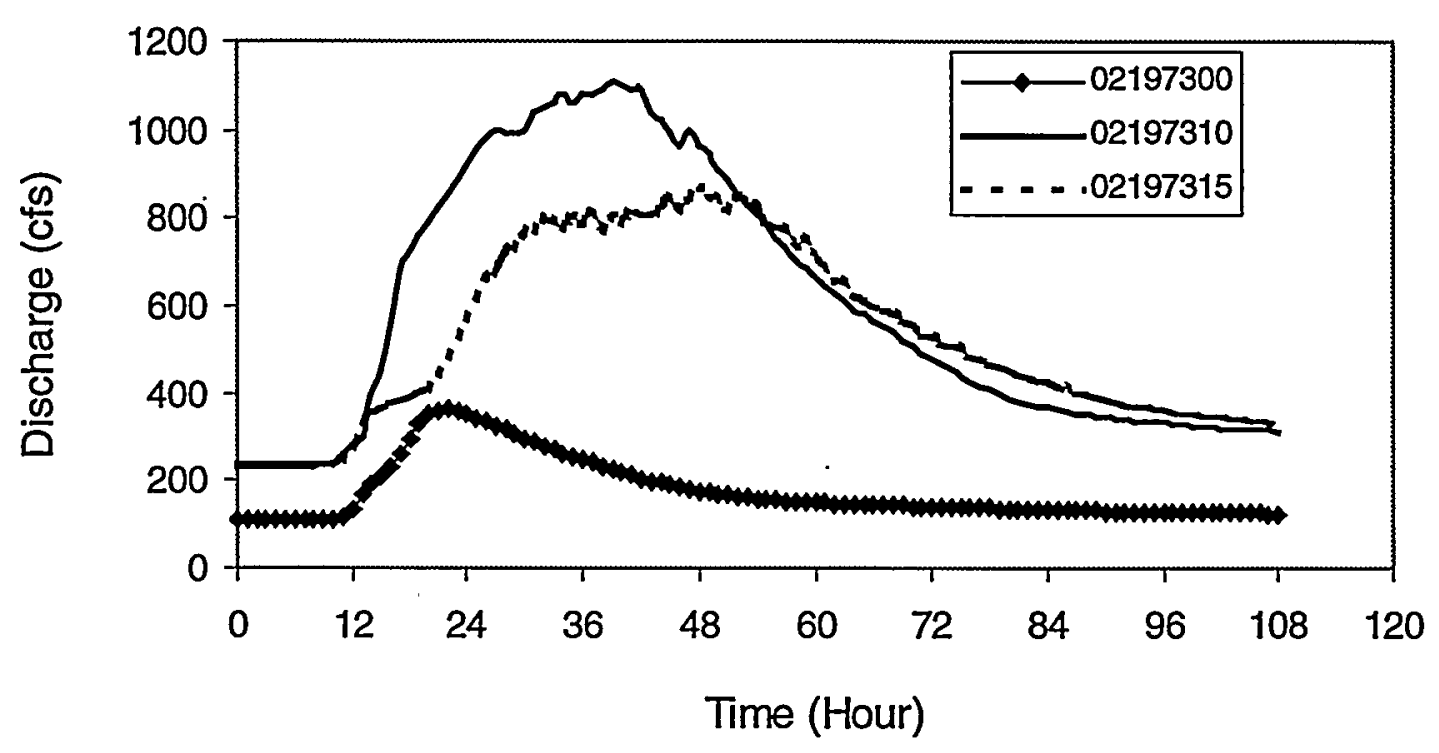




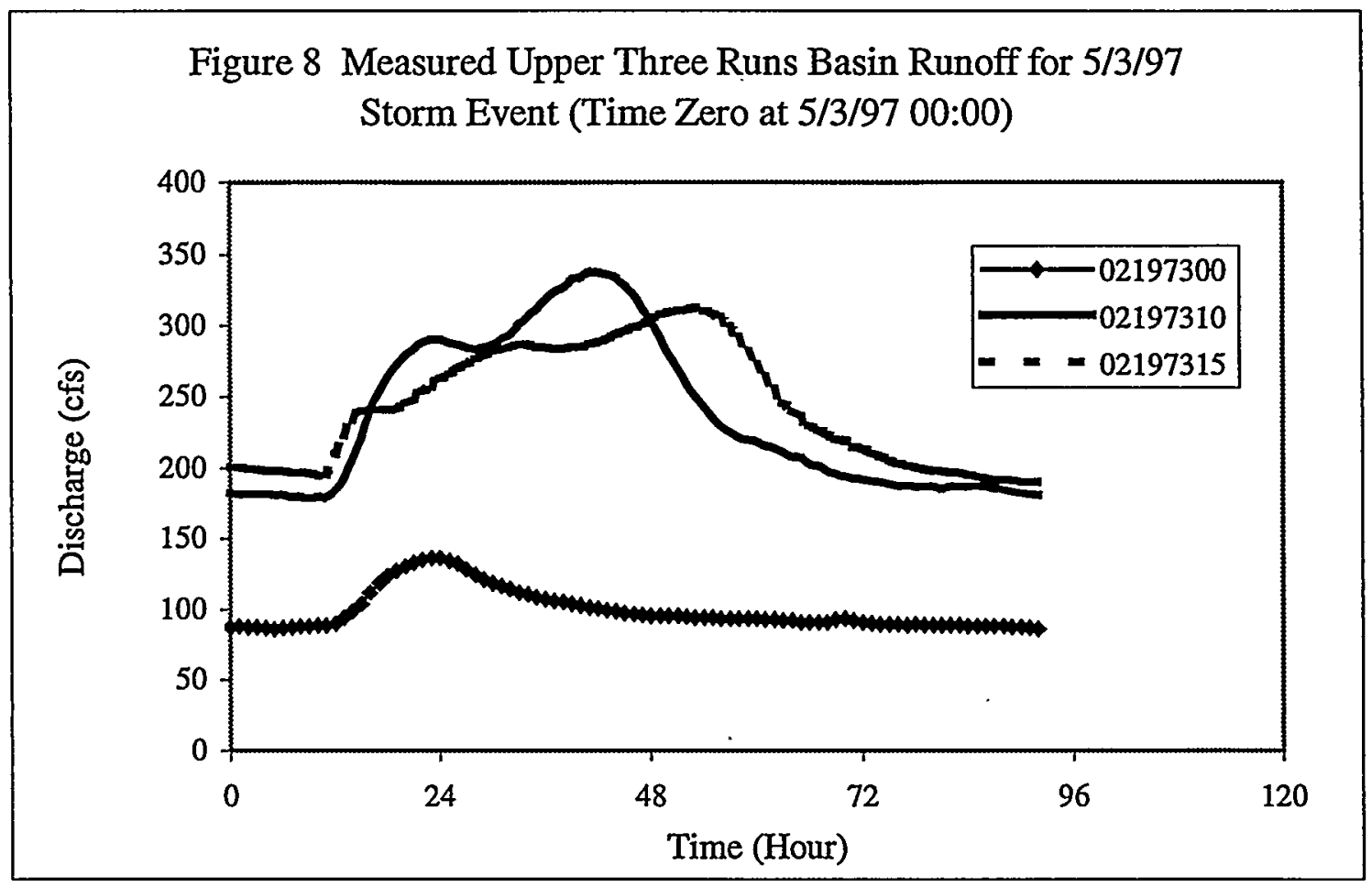





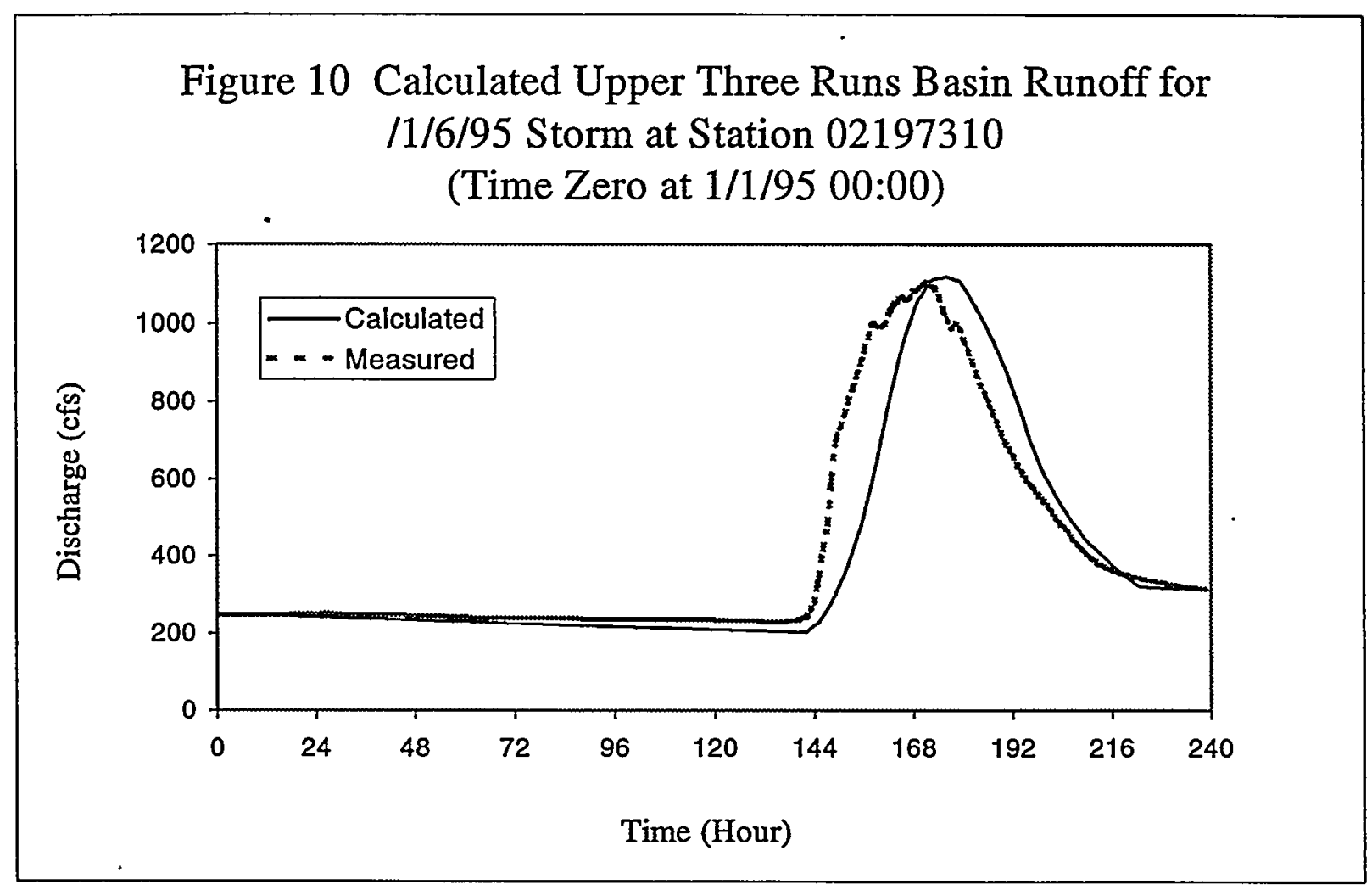




\section{Figure 11 Calculated Upper Three Runs Basin Runoff for 5/3/97 Storm at Station 02197310 (Time Zero at 5/3/97 13:00)}

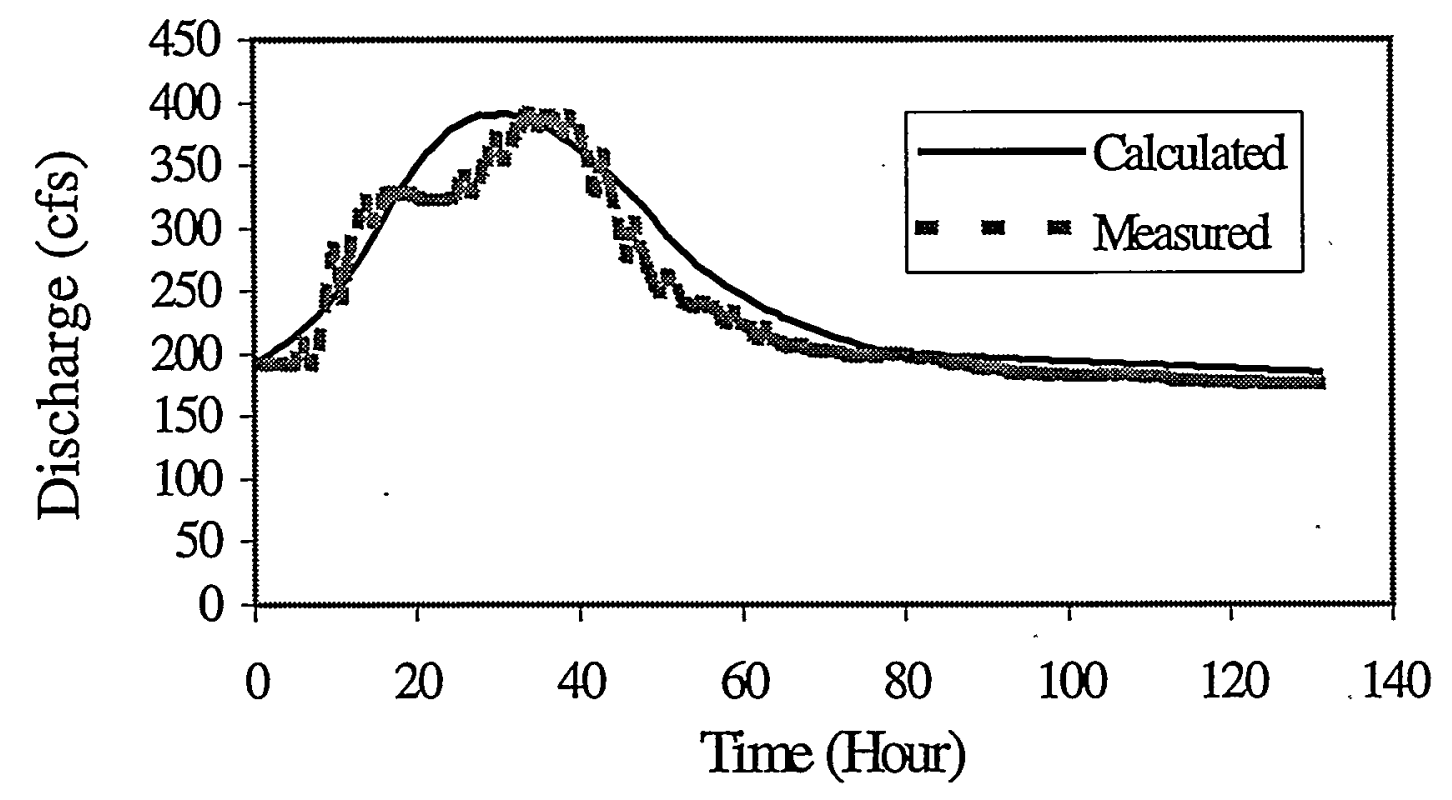


Figure 12 Probability-Discharge for Upper Three Runs Basin at Station 02197310

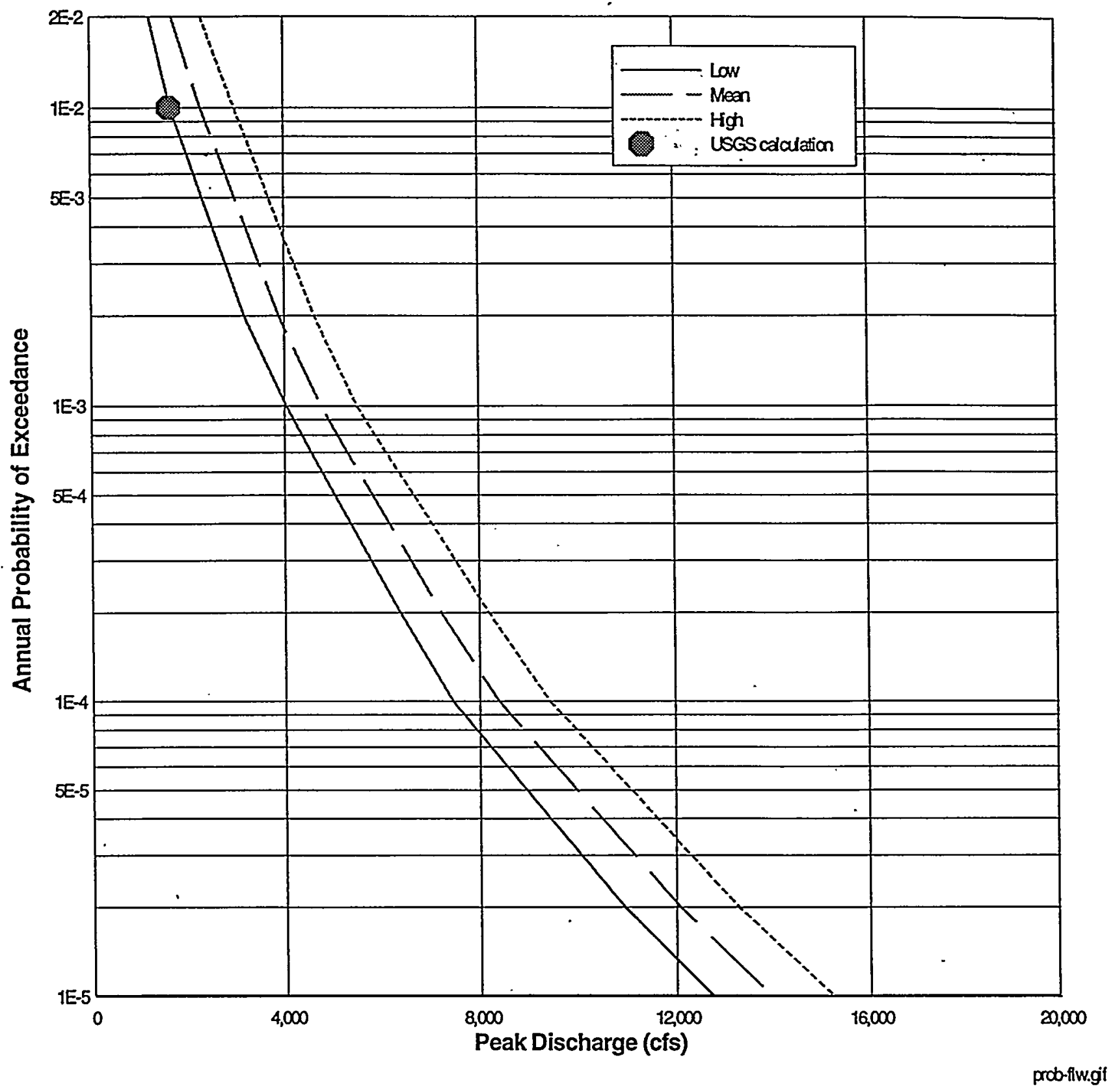


Figure 13 Flood Hazard Curves for Upper Three Runs Basin near F-Area (F-Area elevation above $260 \mathrm{msl}$ )

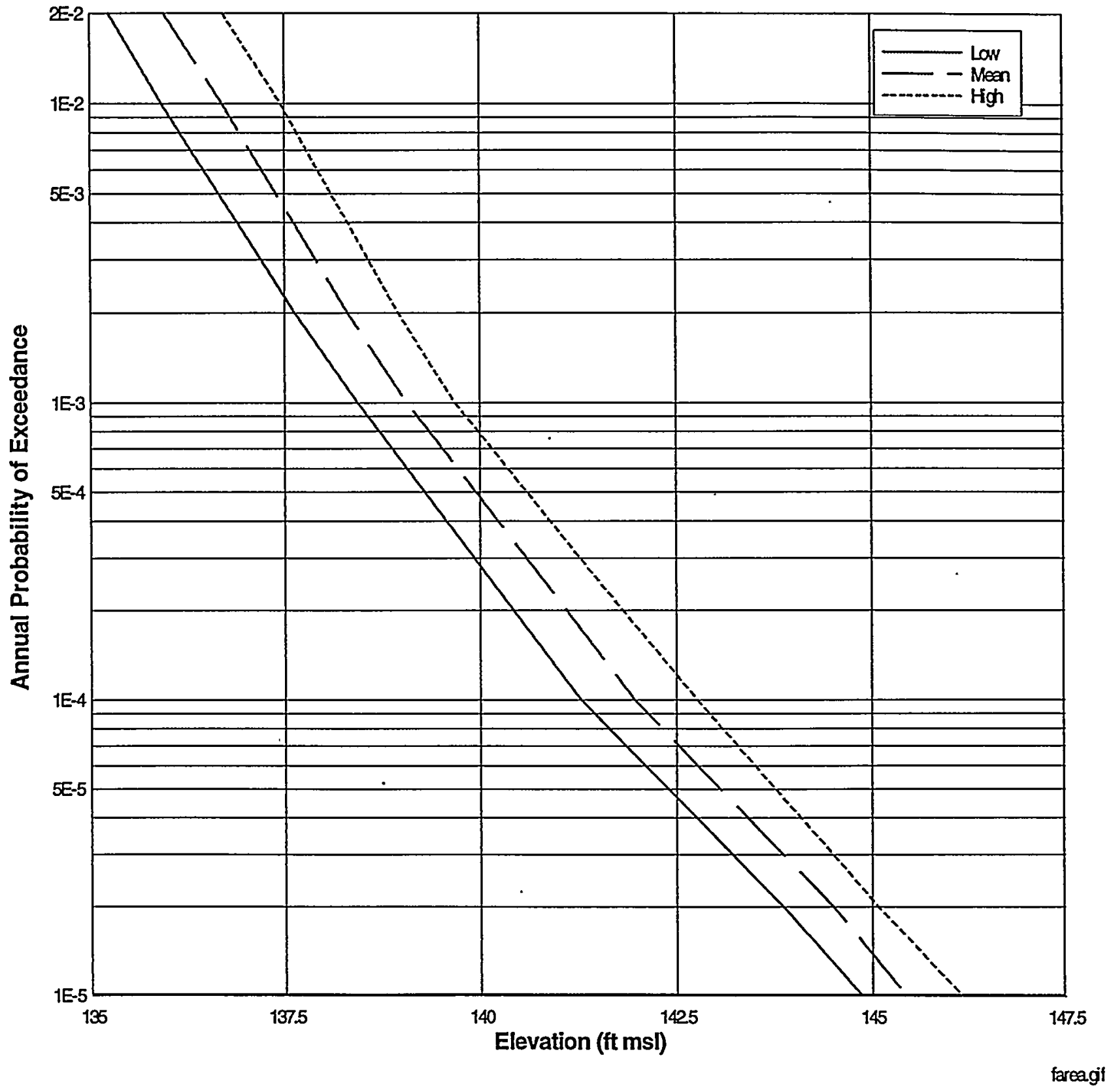


Figure 14 Flood Hazard Curves for Upper Three Runs Basin near S-Area (S-Area elevation above 250 feet $\mathrm{msl}$ ).

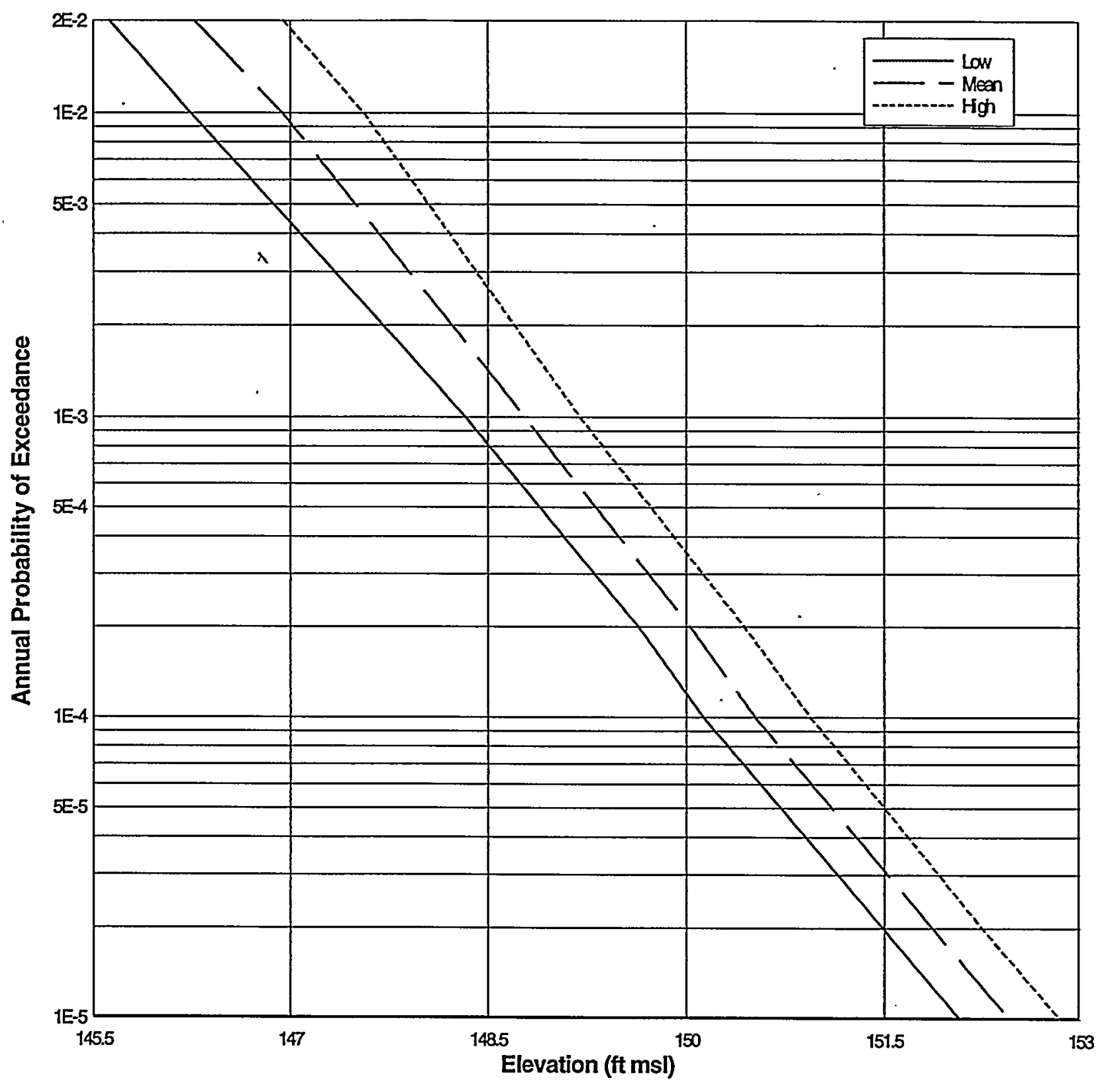


Figure 15 Flood Hazard Curves for Upper Three Runs Basin near Z-and Y-Areas (Z-and Y-Area Elevations above $240 \mathrm{msl}$ )

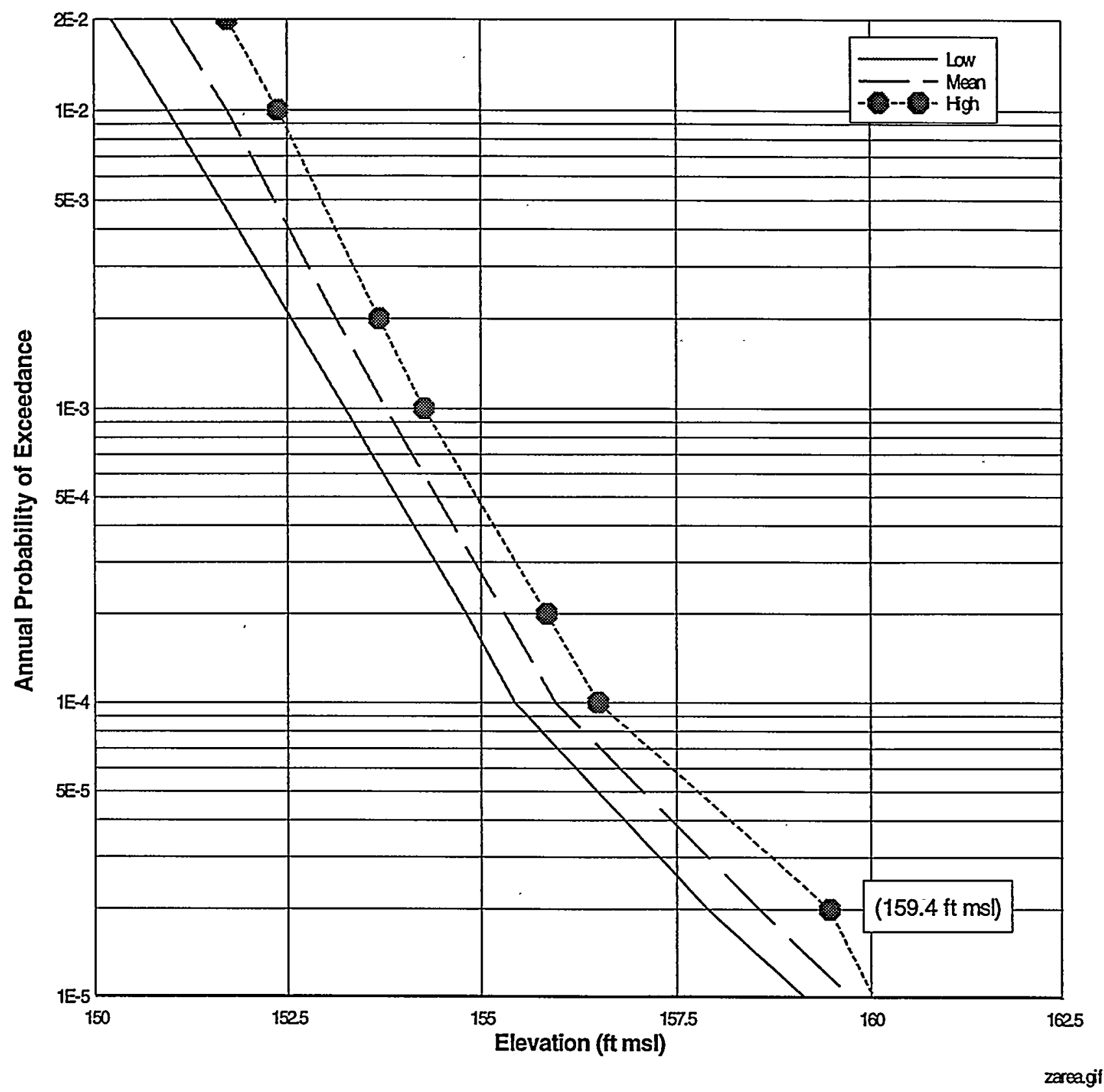


Figure 16 Upper Three Runs Cross Section at Station S146C (near Z-and Y-Areas)

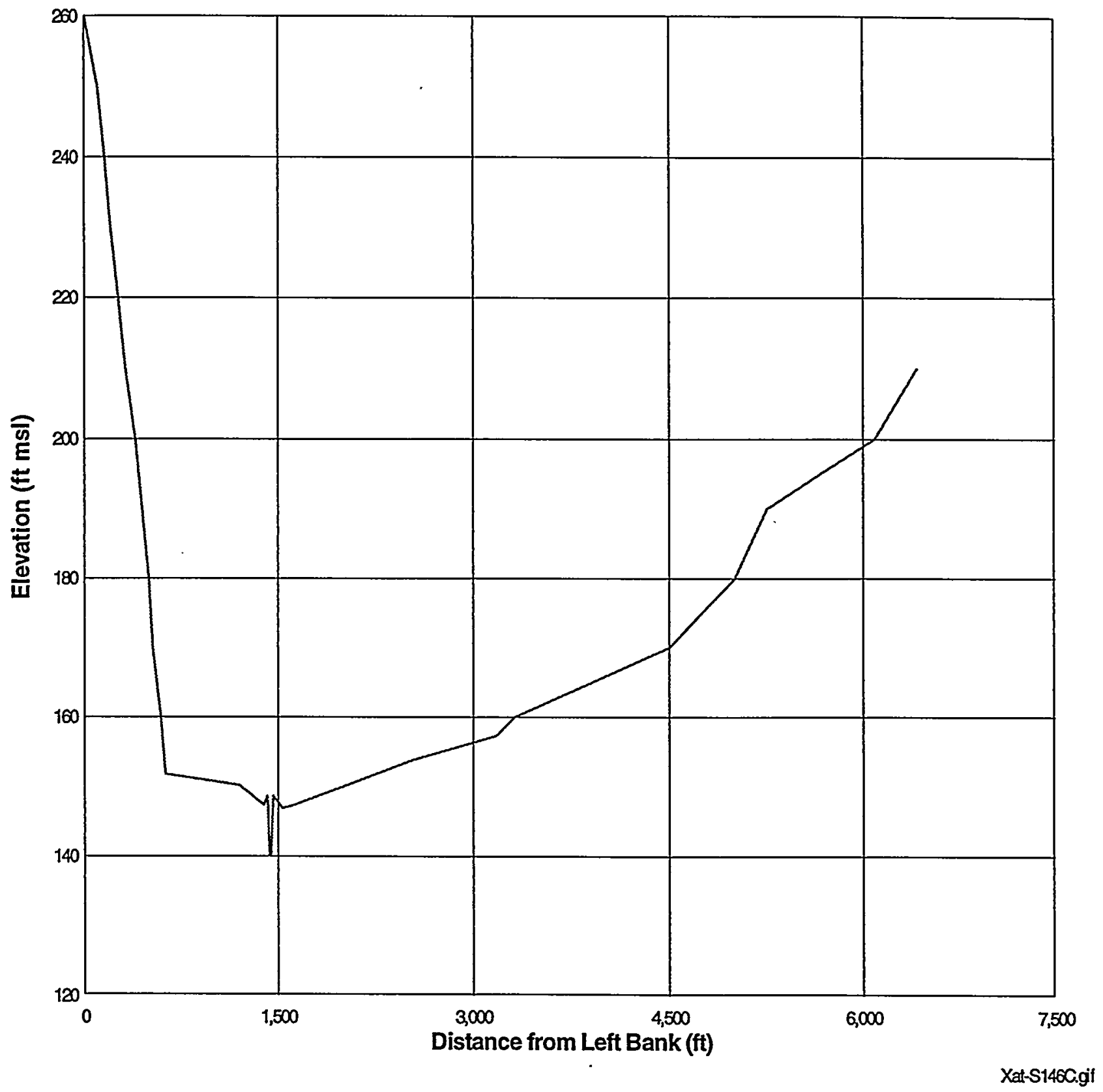




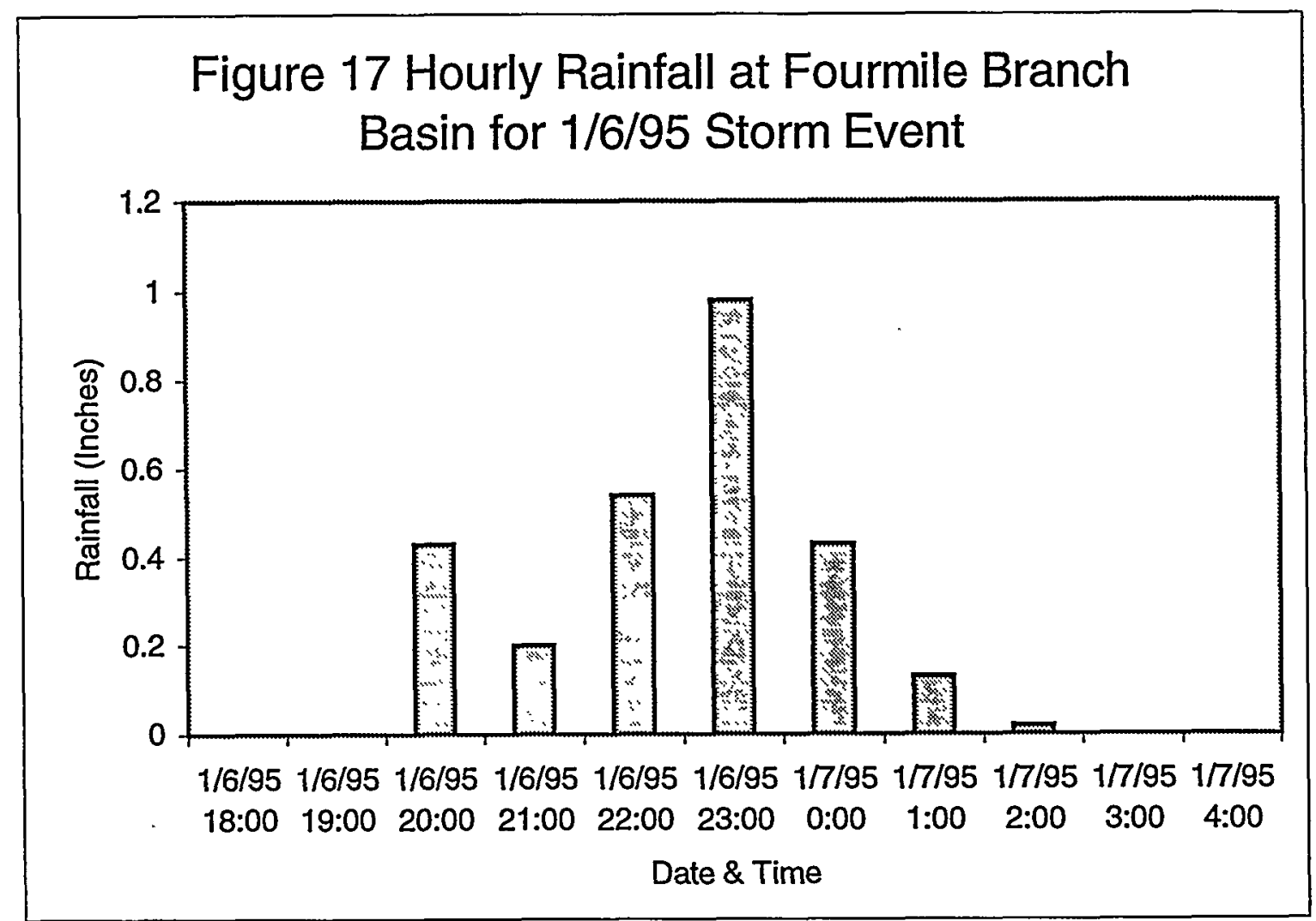




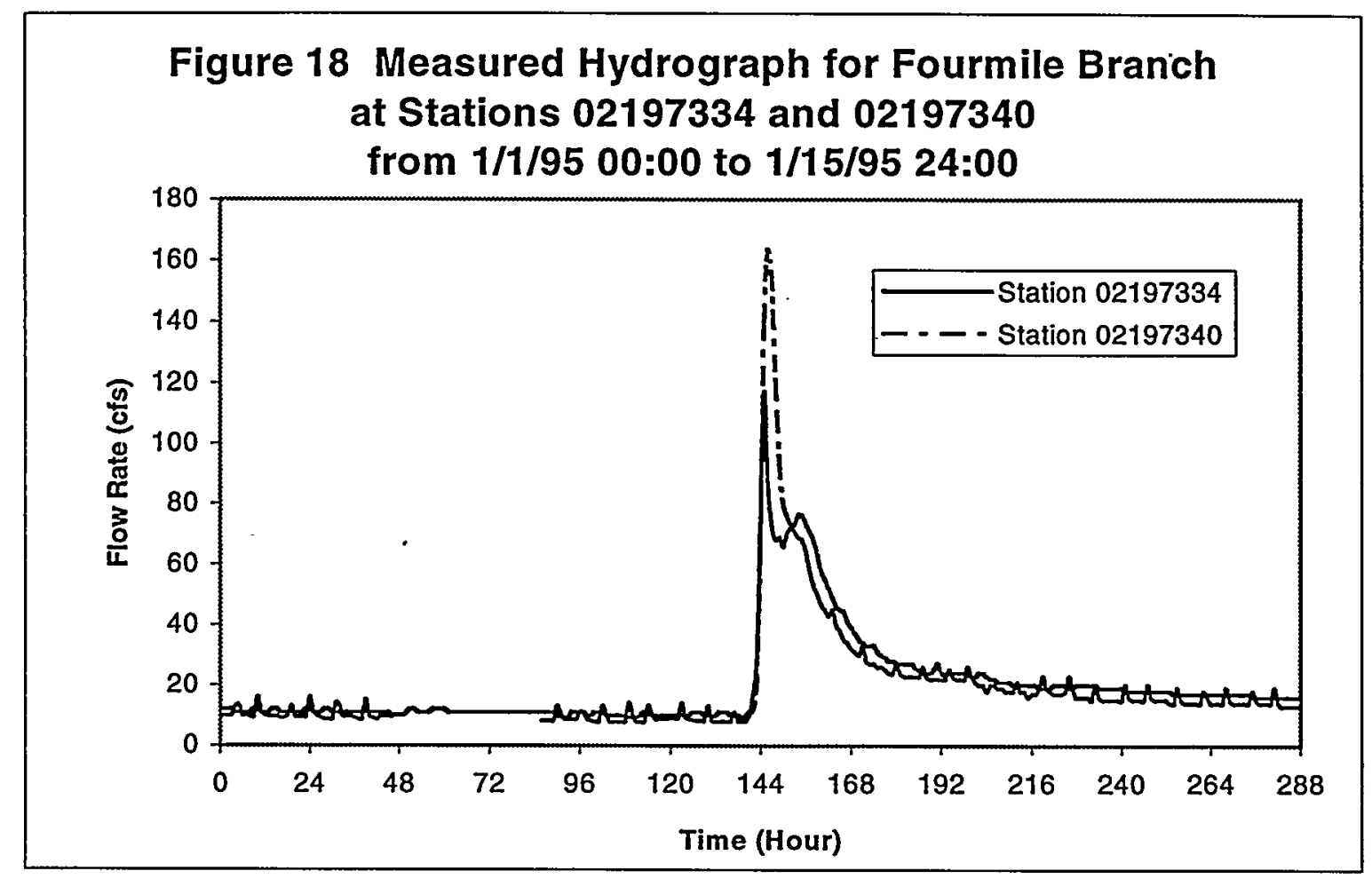




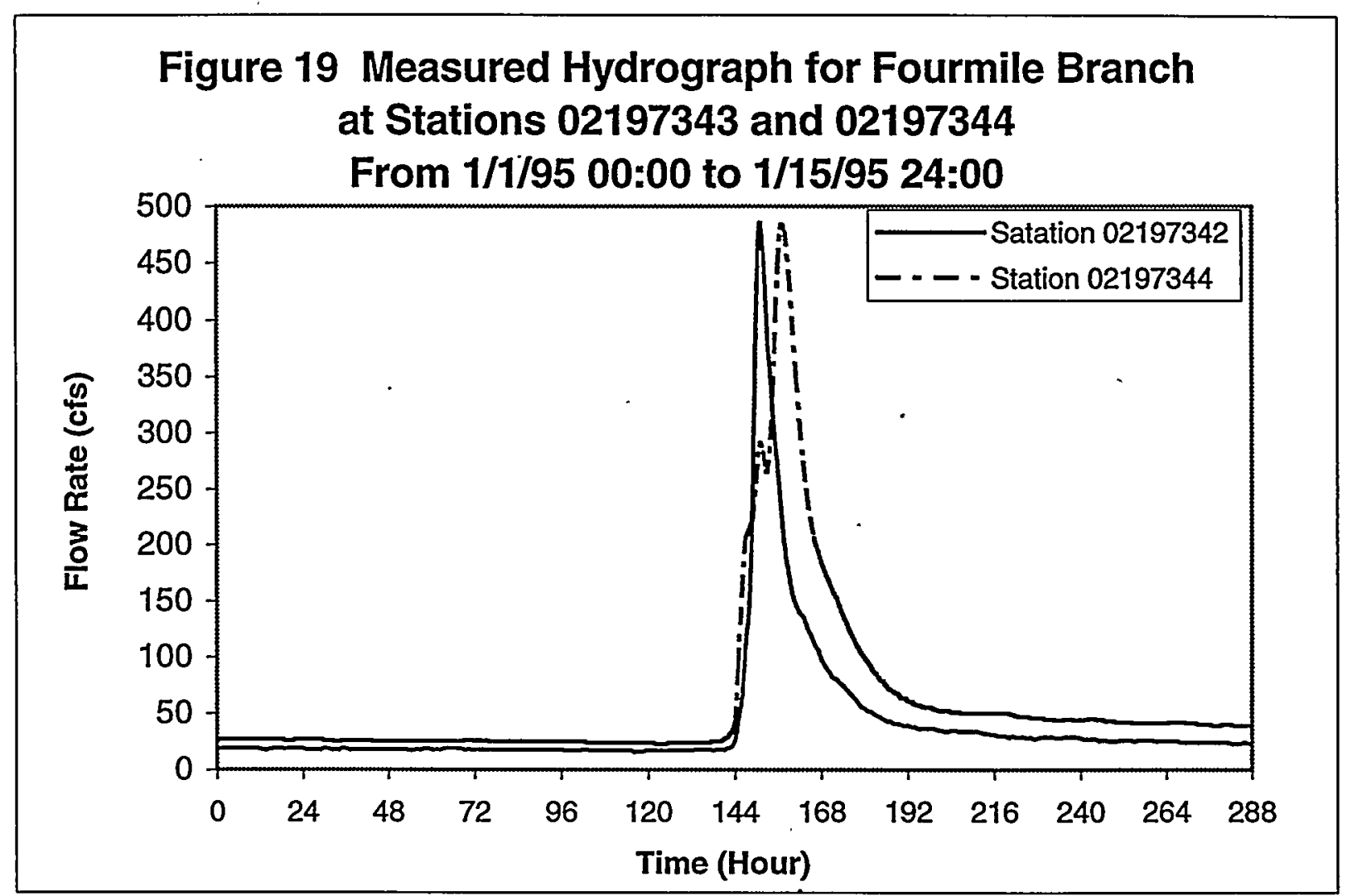


Figure 20 Fourmile Branch Basin Runoff for 1/6/95 Storm at Station 02197334

(Time Zero at $1 / 1 / 9500: 00$ )

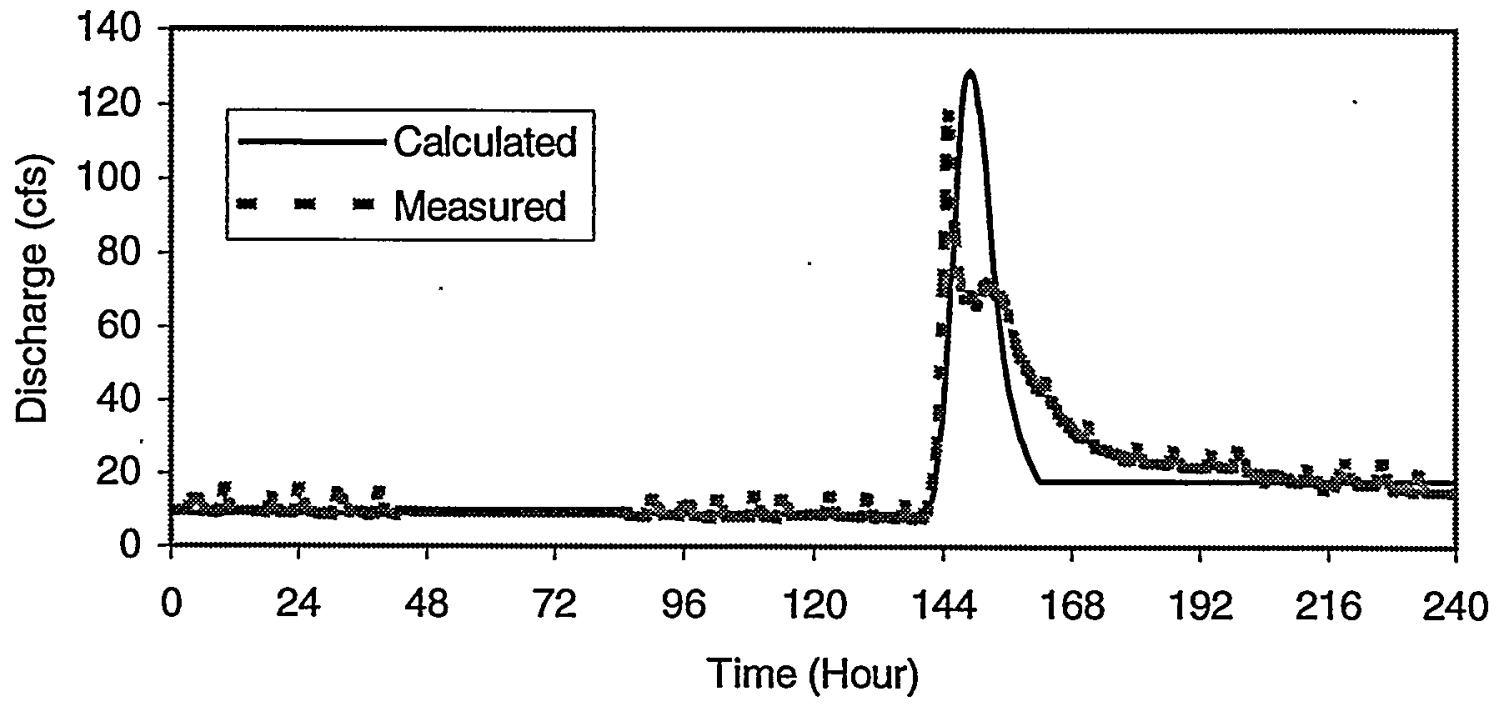




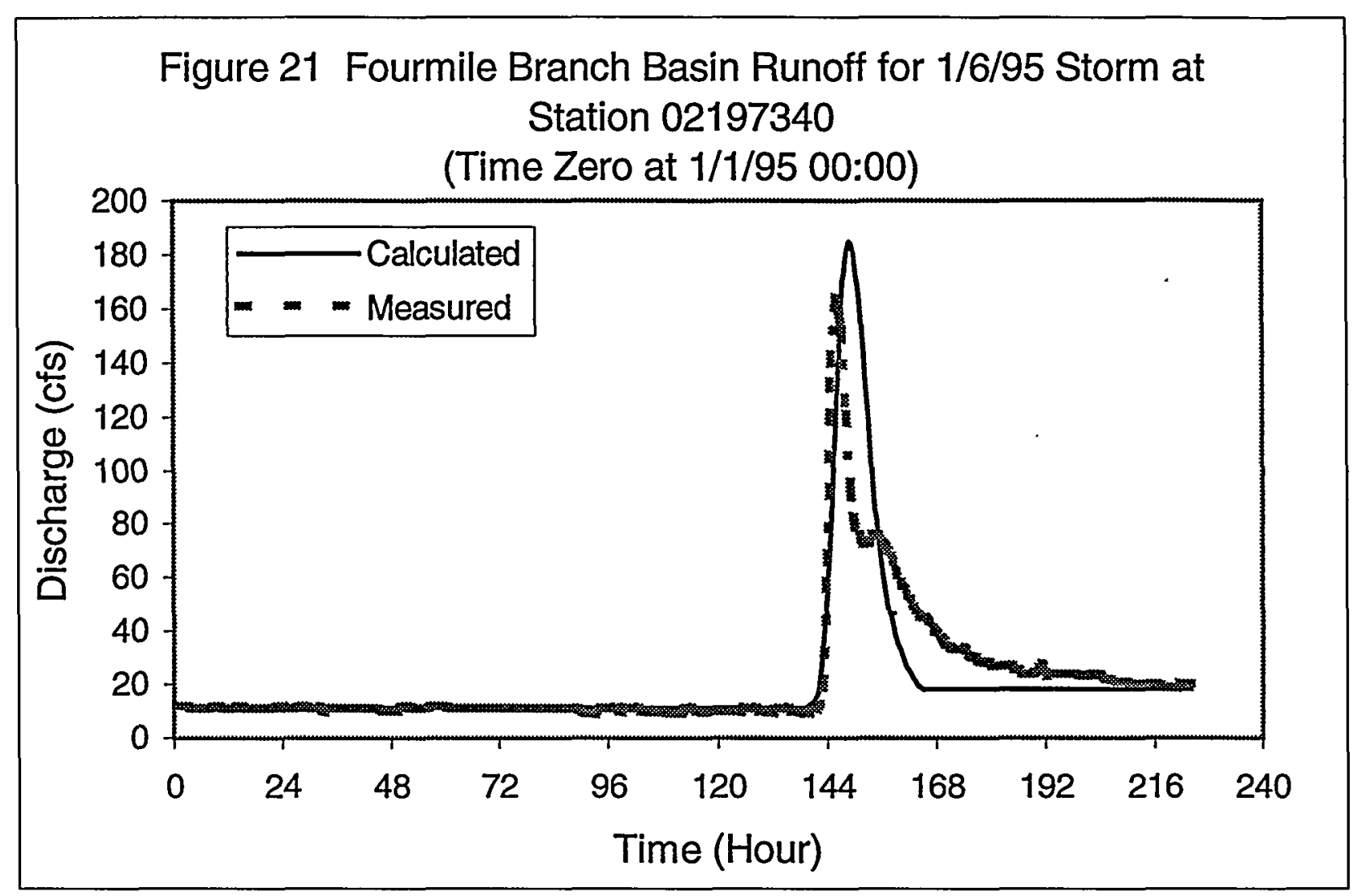


Figure 22 Fourmile Branch Basin Runoff for 1/6/95 Storm at Station 02197342

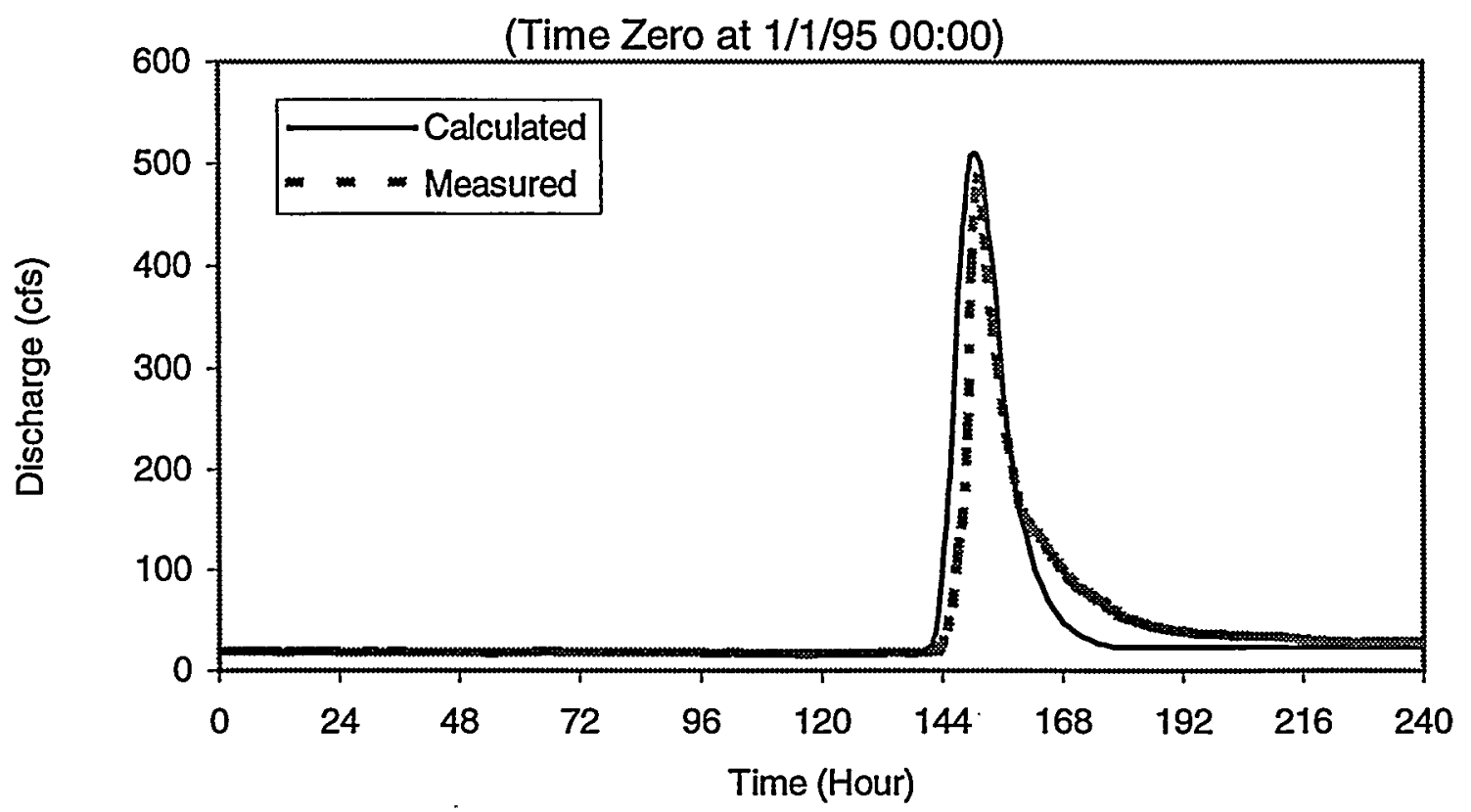




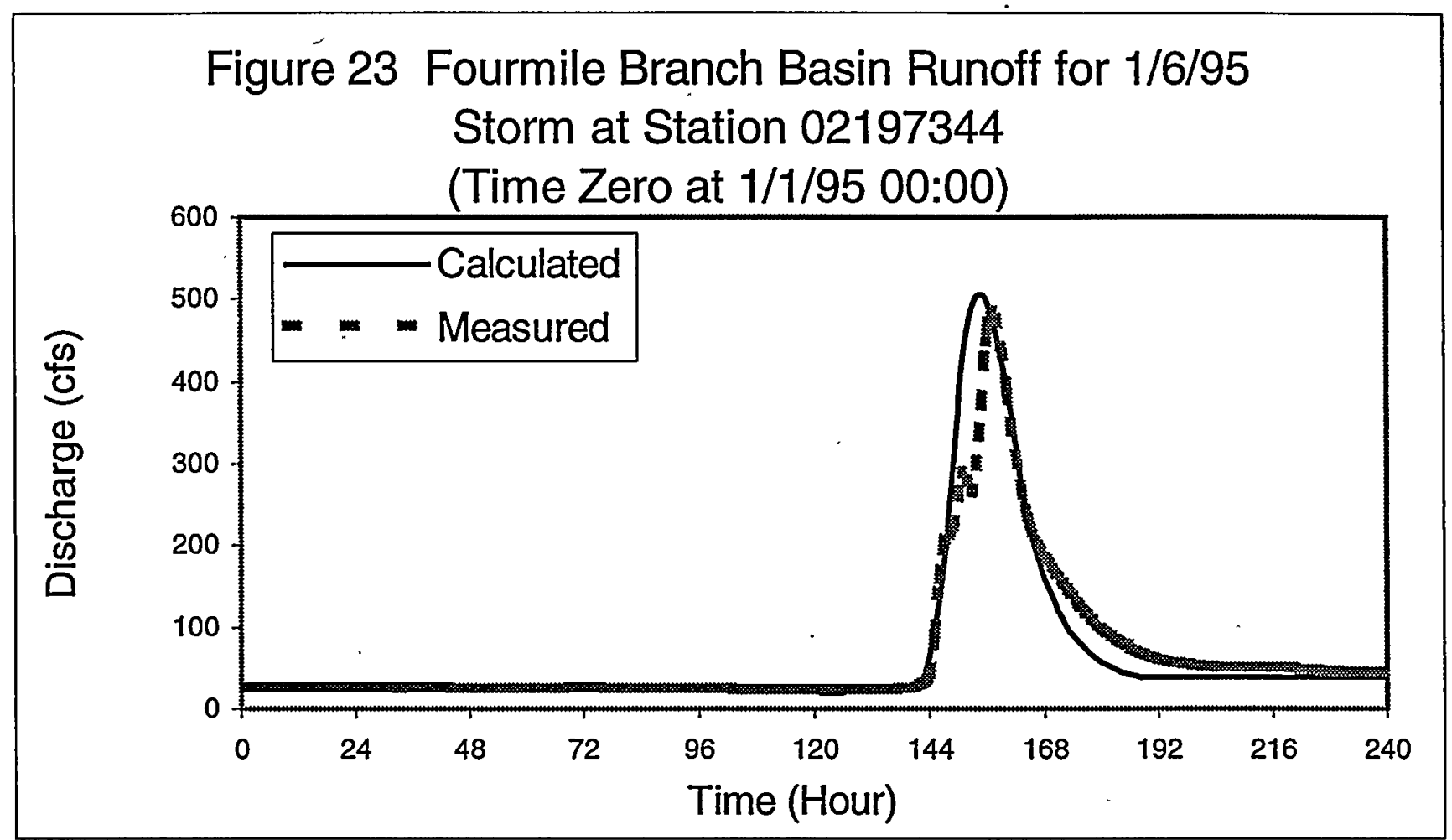




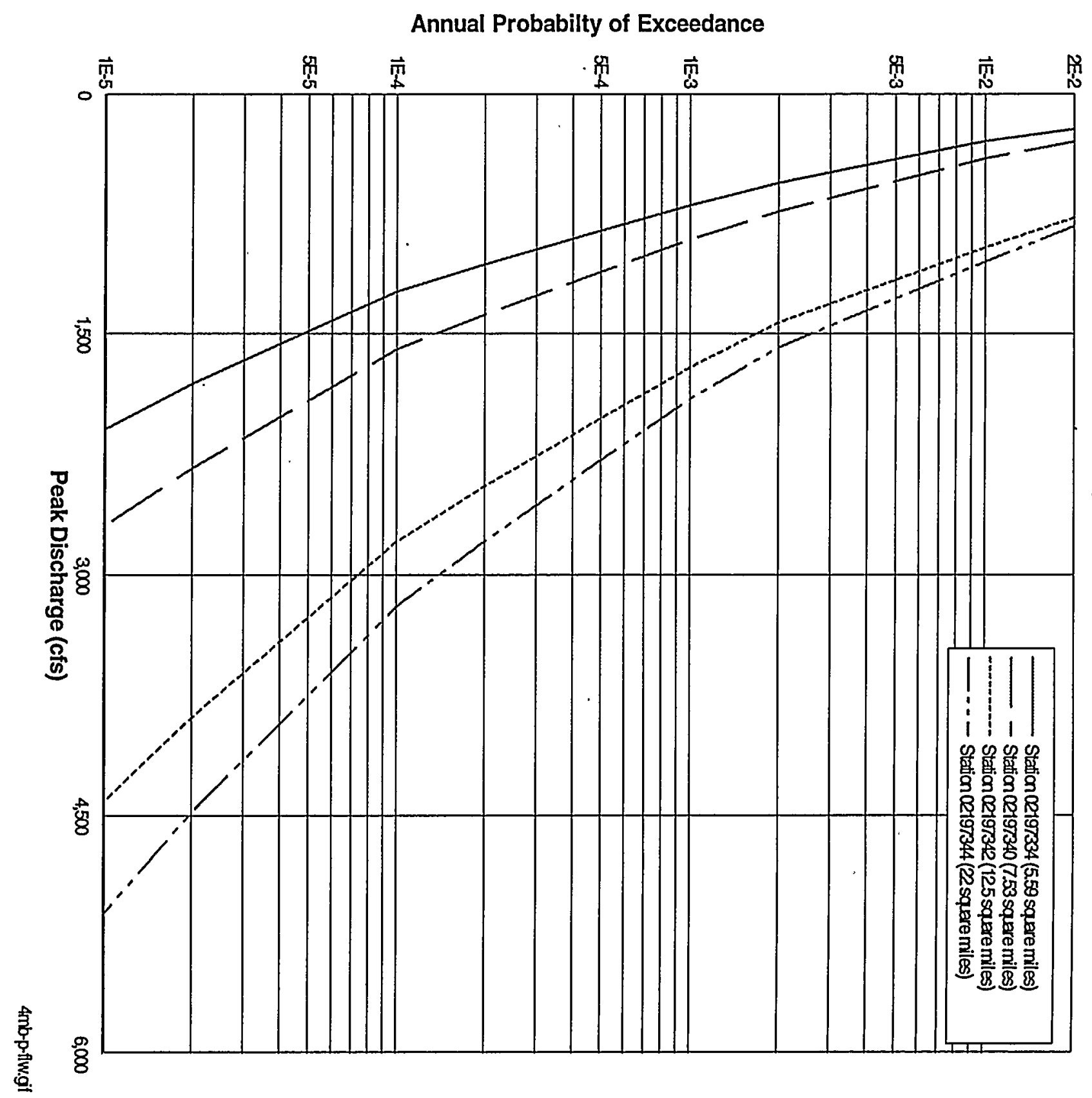

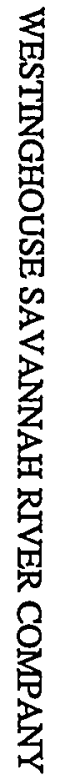

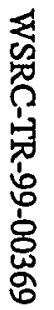


Figure 25 Rating Curve for Culverts at Road E-1 Crossing Fourmile Branch (500-year return flood)

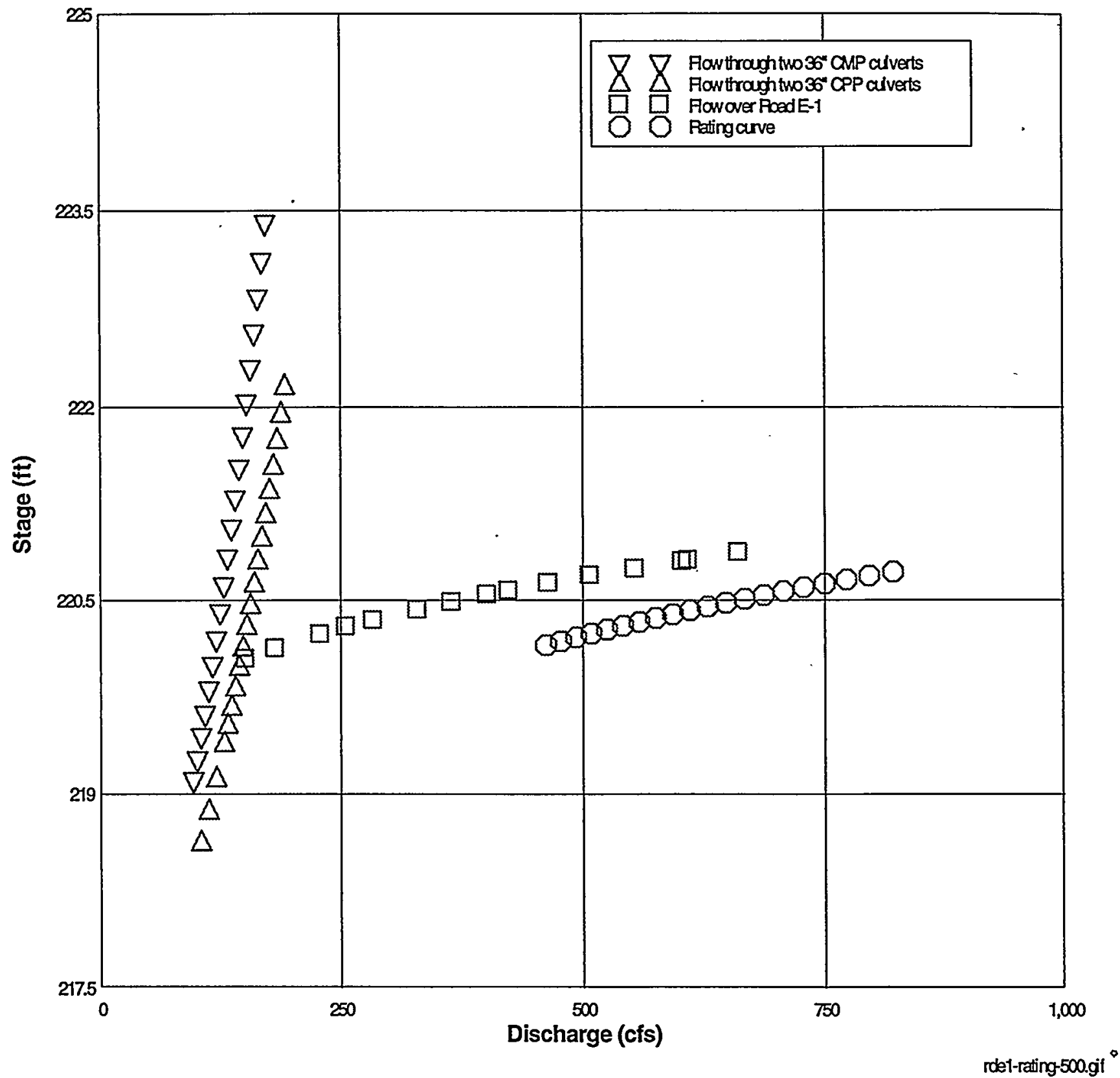


Figure 26 Flood Hazard.Curve for Fourmile Branch Basin near C-Area (C-Area elevation above 280 feet $\mathrm{msl}$ )

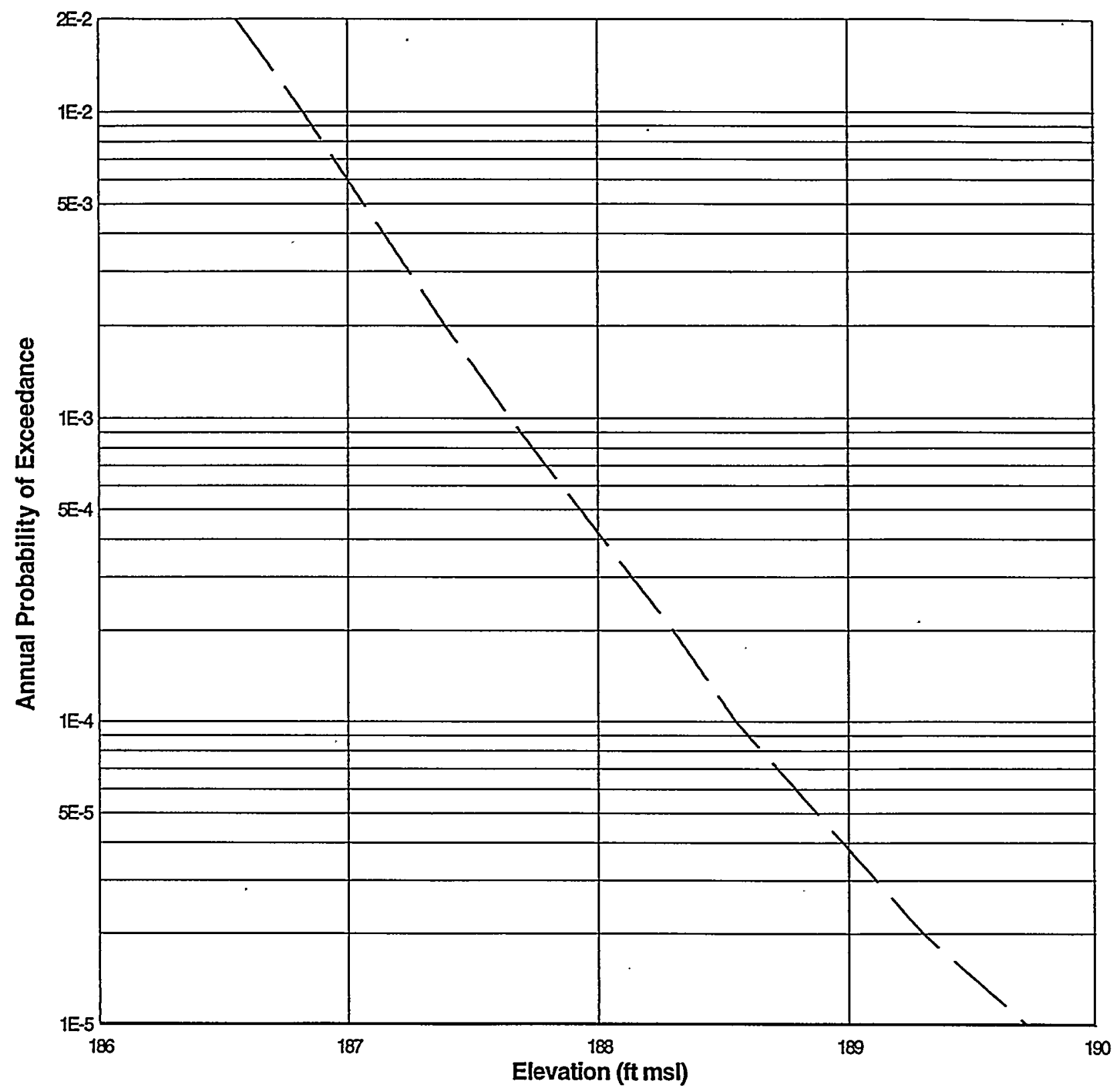

careagif 
Figure 27 Flood Hazard Curve for Fourmile Branch near F-Area (F-Area elevation above 260 feet $\mathrm{msl}$ )

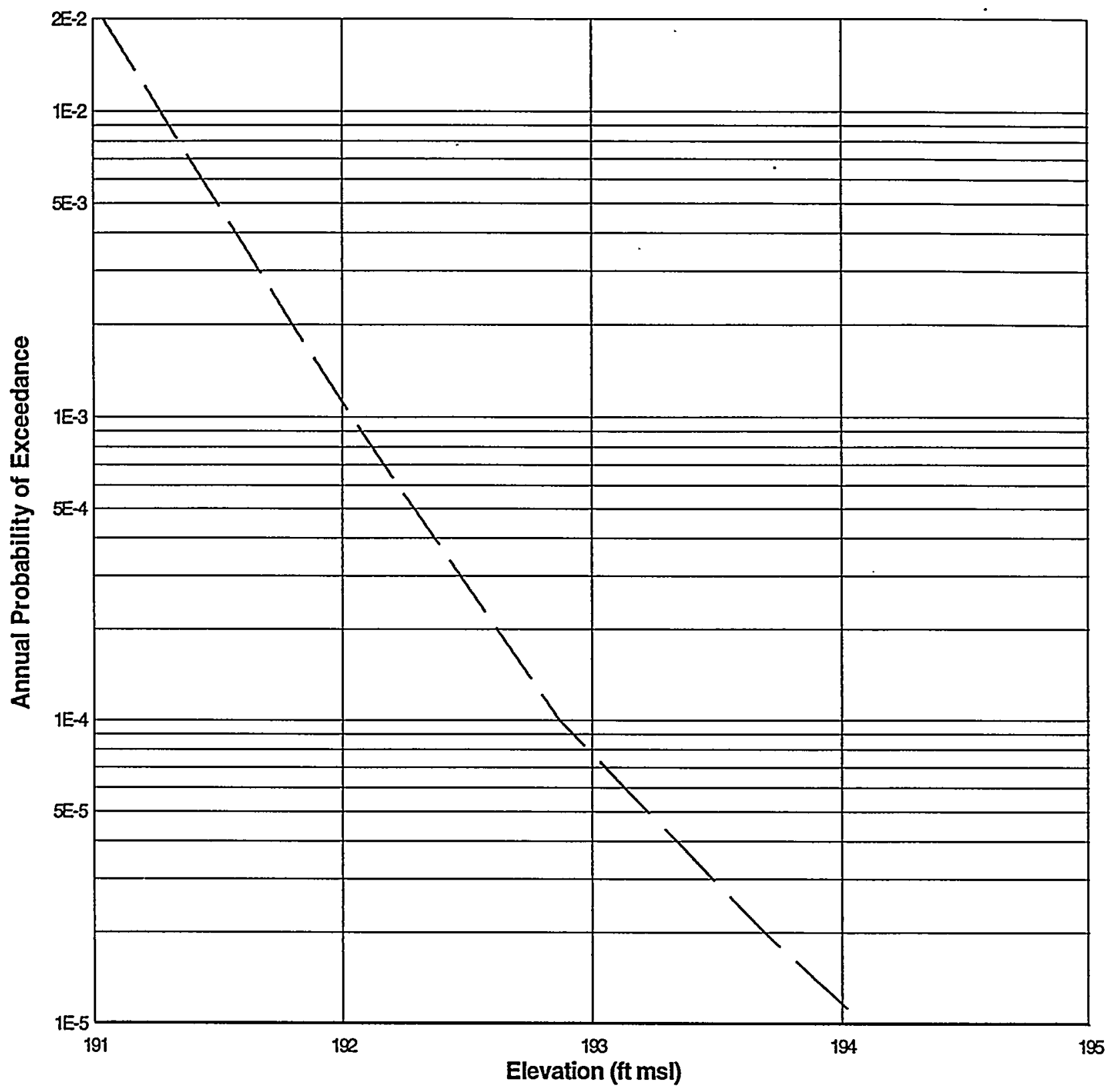


Figure 28 Flood Hazard Curve for Fourmile Branch near E Area (E-Area elevation above 280 feet $\mathrm{msl}$ )

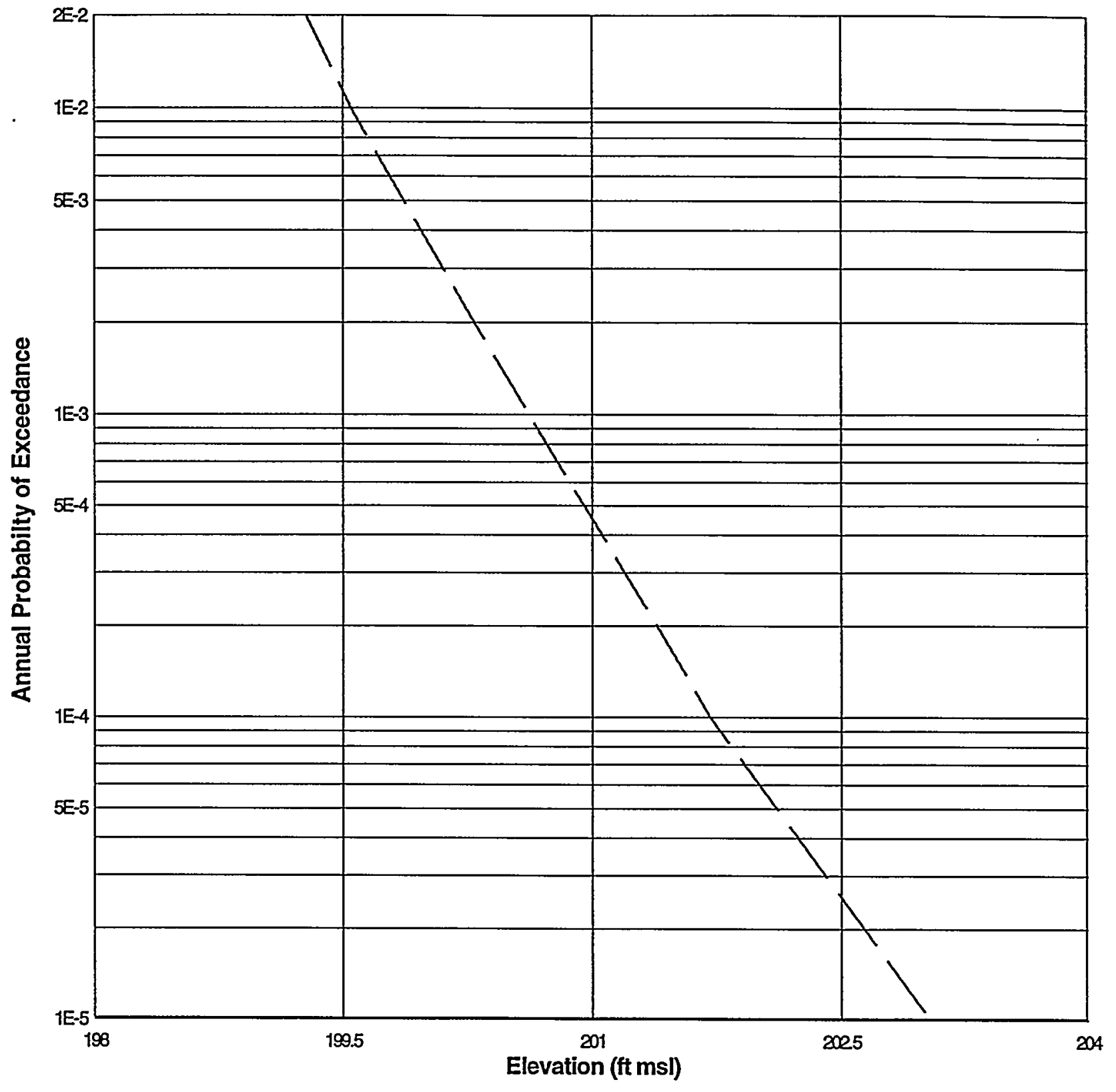


Figure 29 Flood Hazard Curve for Fourmile Branch near H-Area (H-Area elevation above 270 feet $\mathrm{msl}$ )

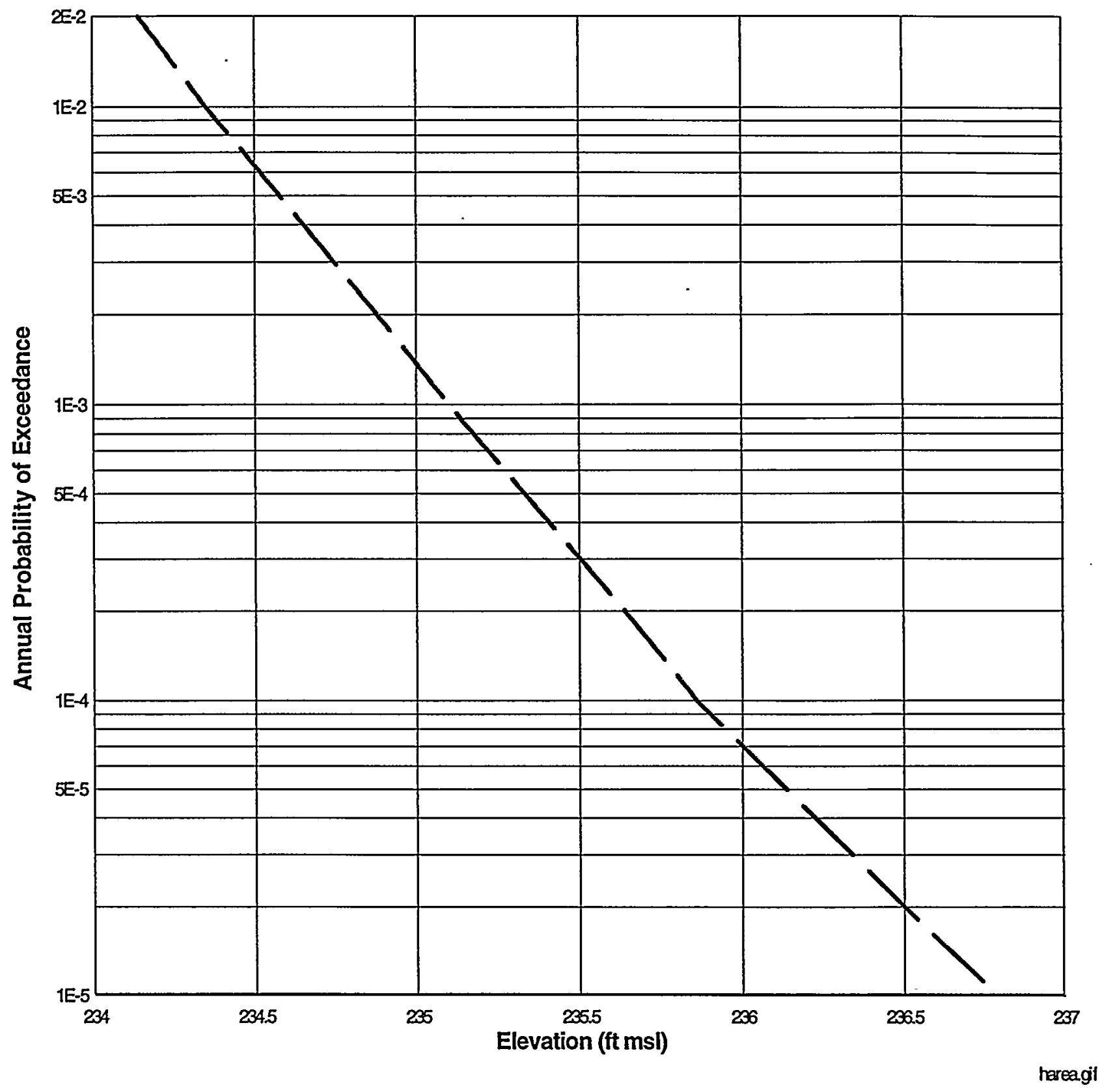


Distribution List:

R.P. Addis, 773-A

A.L. Boni, 773-A

P.T. Deason, 773-A

D.W. Hayes, 735-A

D.P. Griggs, 773-A

Kuo-Fu Chen, 773-A

C.H. Hunter, 773-A

A.H. Weber, 773-A

G.R. Peterson, 703-F

D.C. Hanna, 703-46A

G.R. Whitney, 703A, B222

C.T. Edwards, 703-47A

J.L. Merrick, 703-47A

W.N. Kennedy, 704-60H

F. Loceff, 730-1B/319

G.B. Rawls, 730-1B/313

J.R. Joshi, 730-1B/3068

G.E. Mertz, 730-1B/3080

G.R. Baldwin, 730-1B/3081

J.P. Kelley, 730-1B/3070

L.A. Salomone, 730-2B/130

M.W. Lewis, 730-2B/116

M.E. Maryak, 730-2B/115

B.J. Gutierrez, 703-47A/220

D.P. Matthews, 706-8C

Daniel Wood, 245-7F

R.L. Bandyopadhyay, 730-1B/3083

J. Carroll, 704-N/18

G.E. Driesen, 730-1B/3062

J.J. Gingera, 730-B/3437

M.D. Mchood, 730-2B/1070

R. Palaniswamy, 730-1B/318

ETG files (15 copies) 